\title{
Kapadokya Bölgesi’ndeki Kaya Oyma Depoların Tasarım Ölçütlerinin Sayısal Yöntemlerle Değerlendirilmesi
}

\author{
Evaluation of Design Criteria of Rock-Hewn Storages in \\ Cappadocia Region by Numerical Analyses \\ İsmail DINCCER ${ }^{1} \mathbb{D}$, Mutluhan AKIN ${ }^{1} \mathbb{D}$, Ahmet ORHAN ${ }^{1} \mathbb{D}$, Can DURU $^{2} \mathbb{D}$ \\ ${ }^{I}$ Nevşehir Hacı Bektaş Veli Üniversitesi, Jeoloji Mühendisliği Bölümü, Nevşehir \\ ${ }^{2}$ Nevşehir Hacı Bektaş Veli Üniversitesi, Fen Bilimleri Enstitüsü, Nevşehir
}

Geliş (Received): 10 Nisan (April) 2020 / Düzeltme (Revised): 14 Temmuz (July) 2020 / Kabul (Accepted): 16 Temmuz (July) 2020

\section{ÖZ}

Kapadokya Bölgesi’nde geniş yayılım sunan tüf ve ignimbirit türü piroklastik kayaçlar, sahip olduğu kolay kazılabilirlik ve termal yalıtım özelliklerinden dolayı kaya oyma yapıların oluşturulması için uygun jeolojik koşullar sunmaktadır. Bu kaya oyma yapılardan biri olan kayadan oyma soğuk hava depoları Kapadokya'nın önemli ekonomik değerleri arasında yer almaktadır. Bu çalışmada Kapadokya Bölgesi’nde sayıları yaklaşık 1250 civarında olan kayadan oyma depoların tasarım ölçütleri sayısal analizler yardımıyla incelenmiştir. Bu kapsamda farklı topuk genişliği, örtü kalınlığı ve loca genişliğine sahip modeller göz önünde bulundurulmuştur. Yapilan analiz sonuçlarına göre bölgede açılacak olan kayadan oyma soğuk hava depolarında sırasıyla örtü kalınlığı ve topuk genişliğinin 4 ve 2 metreden az olmayacak şekilde planlanması gerektiği sonucuna varılmıştır. 4 metreden daha az örtü kalınlıkları çekme gerilmelerinin artmasına neden olurken, 2 metreden daha az ayak genişlikleri ise yapının ortasında gerilme artışlarına neden olmaktadır. Bu değerlerden farklı olarak seçilen loca ve topuk genişliklerinde deformasyonlar soğuk hava deposunun ortasında yer alan localarda artmakta ve kaya oyma deponun tamamı tek bir açıklık gibi davranmaktadır. Kaya oyma depolar localar şeklinde planlandığından söz konusu yapıların tasarımında en önemli nokta locaların ayrı birer açıklık gibi davranmasının sağlanmasıdır. Bu koşul uygun loca ve topuk genişliklerinin tasarlanmasıyla mümkün olabilir.

Anahtar Kelimeler: Kapadokya, Kaya Oyma, Depo, Sayısal Analiz, Deformasyon

\section{ABSTRACT}

Tuff and ignimbrite type pyroclastic rocks, which are widespread in the Cappadocia Region, offer suitable geological conditions for the formation of rock-hewn structures due to their easy carving and thermal insulation properties. Natural cold storages, one of these rock-hewn structures, are among important economic values of Cappadocia. In this study, the design criteria of natural rock-hewn storages, the number of which is around 1250 in the Cappadocia Region, were evaluated on the basis of numerical analyses. For this reason, models with different pillar width, overburden thickness and lodge width were taken into consideration. According to analysis results, it is concluded that the overburden thickness and pillar width of rock hewn cold storages to be excavated in the region should be planned not less than 4 and 2 meters, respectively. Overburden thicknesses less than 4 meters lead to increased tensile stresses, while pillar widths of less than 2 meters cause stress increases in the middle section of the storage. Deformations increase at the lodges located in the middle of the cold storage in case of dissimilar lodge 
and pillar width selection, and the entire rock-hewn storage acts as a single opening. Since rock-hewn storages are planned as lodges, the most significant point during the design of these structures is that the lodges should behave as separate openings. This condition can be valid by designing proper lodge and pillar width.

Keywords: Cappadocia, Rock-Hewn, Natural Storage, Numerical Modeling, Deformation

\section{GİRIŞ}

Kaya oyma mekanlar bir kaya kütlesinin çeşitli amaçlar için oyularak şekillendirilmesiyle meydana getirilmekte olup, çoğunlukla insan gücü ile açılmış yeraltı boşlukları kaya oyma yapı olarak sınıflandırılmaktadır (Özata, 2015). Kaya oyma yapılar, farklı jeolojik koşullara ve iklimsel özelliklere sahip, dünyanın farklı bölgelerinde doğal bir yapı türü olarak karşımıza çıkmaktadır. Diğer bir deyişle, bölgenin sahip olduğu fiziksel, kültürel ve sosyal konumu farklı şekillerde kaya oyma yapıların ortaya çıkmasına neden olmuştur (Çorakbaş, 2012). Kaya oyma yapılar ülkemizde başlica Kapadokya Bölgesi’nde gözlenmekte olup, bunun yanı sıra daha az yaygın olarak diğer bölgelerimizde de yeraltı açıklıkları bulunmaktadır. Öte yandan, farklı kaya türlerinin oyulmasıyla Misır'da, Kıbrıs'ta, İtalya'da, İran'da, Ürdün'de, Hindistan'da, İspanya'da, Çin'de ve Etiyopya'da farklı amaçlar için kullanılan kaya oyma mekânlar oluşturulmuştur (Özata, 2015). Hindistan'da kaya oyma yapılar daha çok mezar ve ibadethane olarak kullanılırken, Çin'in Loess platosu gibi bazı bölgelerinde 40 milyona yakın insan "Yaodong Evi " denilen kaya oyma yapıları yaşama alanı olarak kullanmaktadır (Zhu vd., 2014). Kaya oyma yapılar genel olarak gelişigüzel bir iç geometriye sahip olmalarına rağmen, özellikle ibadet amaçlı açılan boşluklarda geleneksel mimaride kullanılan kemer, kolon, kubbe, tonoz gibi formların oyularak oluşturulduğu da görülebilmektedir.

Kapadokya Bölgesi'nde geniş yayılım sunan tüf ve ignimbirit gibi piroklastik kayaçlarda, kolay kazılabilmesi ve termal yalıtım özelliklerinden dolayı geçmişten günümüze çok sayıda kaya oyma mekân oluşturulmuştur. Kaya oyma yapılar işlevlerine göre yaşam ve savunma alanı, ibadet mekânı ve mezar yapısı olmak üzere dört ana sınıfa ayrılabilir. Kapadokya'daki Bizans kültürünü yansıtan kaya oyma boşluklar sadece mezar ve kiliselerden değil, aynı zamanda manastır ve yaşam alanlarından da oluşmaktadır (Berndt-Ersöz, 2006). Kapadokya Bölgesi'nde 1500 yıldan daha yaşlı birçok kaya oyma yapı bulunmakta olup, bunların diş görünümleri doğal morfolojiye uygun bir yap1 sergilerken, iç mekânlarında ise oldukça karmaşı ve detaylı bir geometrinin olduğu gözlenmektedir (Aydan ve Ulusay, 2003). Sülükçü (2019) tarafından Kızılkaya ignimbiritlerin dışında diğer ignimbiritlerde açılmış depoların özellikle girişlerine yakın kesimlerinde ayrışmaya ve tavan bölümünde ise jeolojik faktörlere bağl1 olarak bazı duraysızlıkların gelişebileceği belirtilmiştir. Farklı boyut ve şekillerde kazılmış olan bu yeraltı açıklıkları günümüzde de konaklama, yaşam ve depolama amaçlı kullanılmaktadır. Bölgede halen turizm ve depolama amaçlı yeraltı mekânların oluşturulmasına devam edilmektedir.

$\mathrm{Bu}$ çalışmada Kapadokya Bölgesi’nde sayıları yaklaşık 1250 civarında olan kayadan oyma depolar, tasarım ölçütleri açısından ele alınmıştır. $\mathrm{Bu}$ kapsamda depoların mevcut tasarım geometrileri sayısal analizler yardımıyla incelenerek en uygun tasarım boyutlarının belirlenmesi amaçlanmıştır. Bu amaç için bölgede yaygın olarak kullanılan kaya oyma depoların mimari projeleri üzerinden farklı boyutlar sonlu elemanlar yöntemine göre analiz yapan RS2 (Rocscience, 2019a) yazılımı ile incelenmiştir. 
Son dönemde bölgede açılan kaya oyma depolar, mimari açıdan bir koridor ve bu koridora bağlı localar şeklinde planlanmakta olup, bu boyutlandırma çoğunlukla geçmiş dönemlerde elde edilen kişisel tecrübelere dayanmaktadır. $\mathrm{Bu}$ çalışma kapsamında localar arasındaki ayak/ topuk genişliği, loca genişliği ve örtü kalınlığ 1 gibi boyut parametreleri düşey gerilme ve toplam deformasyon gibi parametreler üzerinden sayısal olarak değerlendirilmiştir. Elde edilen sonuçlar karşılaştırılarak ekonomi ve güvenlik koşulları açısından kabul edilebilir boyutlar ortaya konulmuştur. Elde edilen sonuçlara bağlı olarak hassasiyet grafikleri oluşturulmuş ve mevcut yönetmelikte tanımlanan tasarım ölçütleri ile karşılaştırılmıştır. Böylece bölgesel anlamda optimum tasarım ölçütleri önerilmiştir.

\section{KAYA OYMA DEPOLAR}

Kapadokya Bölgesi'nde piroklastik kayaçlar içerisinde oluşturulan kaya oyma soğuk hava depolarının geçmişi Hititlere kadar uzanmaktadır. Yöre halkı tarafından "Ayça" adı verilen kaya oyma depolar1, Hititlerden sonra Romalılar, Bizanslılar, Selçuklular ve Osmanlılar tarafindan da aynı amaçla kullanılmıştır. Bölgedeki önemli ekonomik faaliyet alanlarından biri olan kaya oyma depolarda, narenciye türlerinin yanı sıra, patates, soğan, elma, armut gibi meyve-sebze çeşitleri de depolanmaktadır. Bunun yanında, sınırlı miktarda kültür mantarı yetiştiriciliği de yapılmaktadır (Harunoğulları ve Kayar, 2012). Kapadokya Bölgesi'nde soğuk hava depolarının kullanımını ağırlıklı olarak limon, patates ve tohumculuk oluşturmakta olup, Ortahisar ve Kavak bölgesinde çoğunlukla limon depolanırken, Çat ve Nar bölgesindeki depolar patates ve tohumculuk üzerine faaliyet göstermektedir. Mekanik ve elektronik aksamlı soğuk hava depolarından farklı olarak kaya oyma depolarda sıcaklık tüm y1l boyu ortalama $8^{\circ} \mathrm{C}$ 'dir ve bu sıcaklığın ayarlanması için elektrik kullanılmamaktadır. Öte yandan, kaya oyma depolarda saklanan patates ve limon gibi baz1 ürünlerin ağırlıklarında doğal nemden dolayı $\% 10$ civarında artış da görülmektedir. Bölgedeki kaya oyma depolarının kapasitesi genelde 100 ile 1000 ton arasında değişmekte olup, bir ya da birkaç galerili küçük ve orta ölçekli depolar halinde Kavak, Ortahisar, Şahinefendi, Kaymaklı, Mazı, Nar ve Çat köyleri mevkilerinde yoğunlaşmıştır. Söz konusu lokasyonların dışında birçok köy ve belde sınırları içerisinde kaya oyma depolar yer almaktadır (Şekil 1). Tarım İl Müdürlüğü verilerine göre bölgede toplam 1226 adet kaya oyma soğuk hava deposu bulunmakta olup, bu depoların toplam kapasitesi yaklaşık 1.5 milyon tondur. Kavak kasabas1 379 adet ve 810000 ton kapasite ile kaya oyma depo açısından bölgede birinci surada yer almaktadir. Ortahisar, 363 adet kaya oyma depo ve 98000 ton kapasiteye sahiptir. Son y1llarda ise projeli tesis edilen 5000-20000 ton kapasiteli depolar patates endüstrisinin gelişimi ile birlikte artmıştır. Bu tip kaya oyma depolar Nevşehir Merkez, Nar ve Çat kasabaları sınırları içerisinde yer almaktadır. Gülşehir yolu boyunca yer alan bu kaya oyma depolar büyük kapasiteleri ve teknolojik özellikleri ile dikkati çekmektedir. Söz konusu bölgede 102 adet kaya oyma depo faaliyette olup, kapasitesi 507000 ton civarındadır.

Bölgedeki kaya oyma depolar önceleri vadi yamaçları boyunca volkanik kökenli tüflerin el aletleriyle kazılması sonucu oluşturulurken, günümüzde iş makinaları kullanılarak her türlü topoğrafyada açılabilmektedir (Şekil 2a ve b). Son dönemde açılan kaya oyma depolar oldukça büyük hacimli olup, içerisinde rahatlıkla kamyon, tır vb. araçlar ilerleyebilmektedir. Ancak Ortahisar ve Kavak bölgesinde yer alan bazı depolar oldukça küçük olup, araçlar bazı depo içlerine girememektedir (Şekil 2d). Bu 
durumda ürünler insan gücü ile depo içerisine taşınmaktadır. Yeraltı depoları, yapısal olarak 2-3 metre kalınlığındaki kolon ve duvarların termal yalıtımı ile duraylı bir depo içi sıcaklığına sahip olup, y1l boyunca yeraltında depolanan ürünleri $4-10^{\circ} \mathrm{C}$ arasında tutmaktadır. Eski dönemlerde açılmış olan depolarda düzenli bir mimari proje gözlenmezken, son dönemde inşa edilen kaya oyma depolarda koridor ve koridora açılan localardan oluşan düzenli bir mimari proje dikkati çekmektedir (Şekil 2c ve Şekil 3).

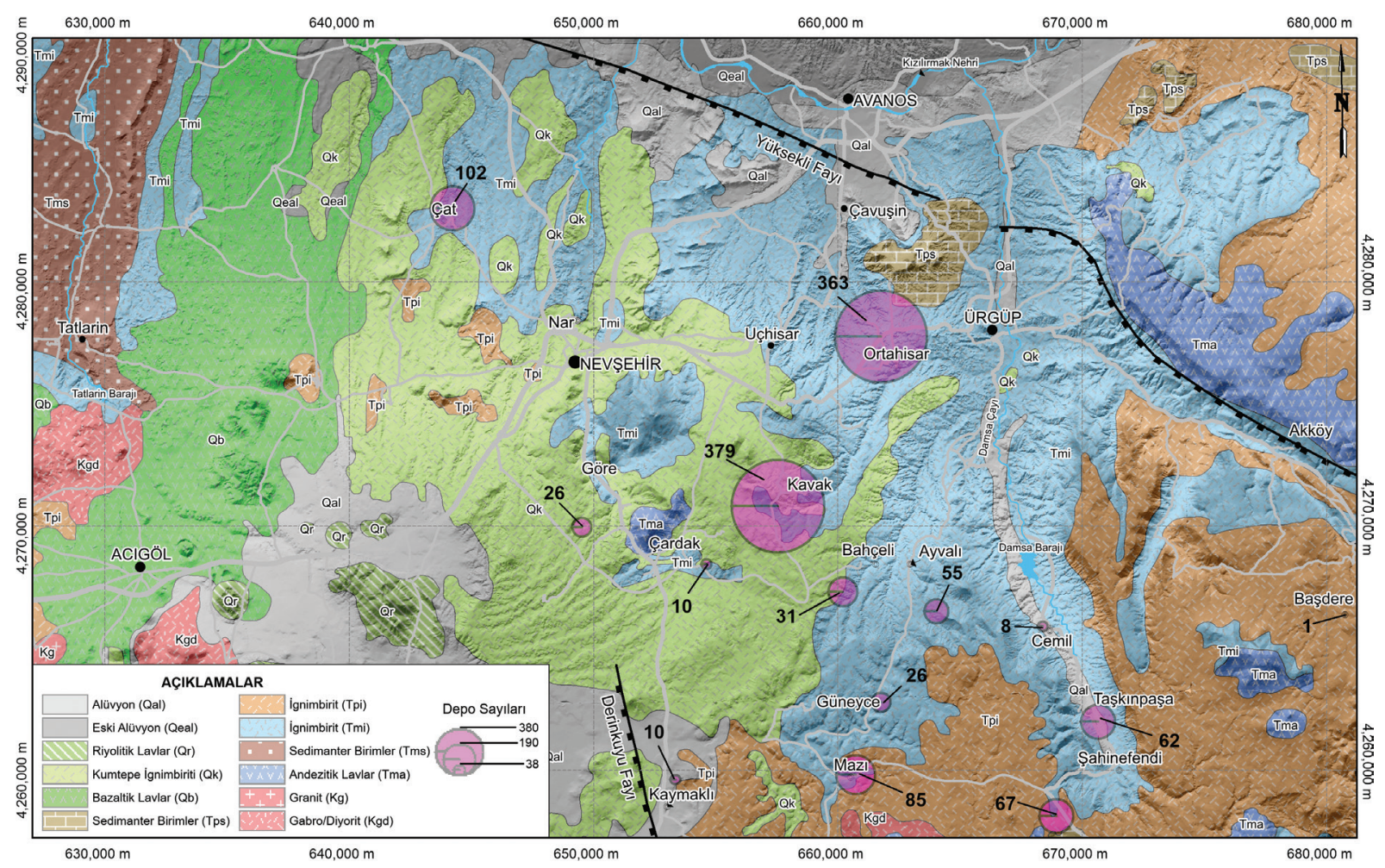

Şekil 1. Kapadokya Bölgesi’nde kaya oyma depoların sayısal dağılımı ve jeolojik birimlerin genel yayılımı (Aydar vd., 2012'den değiştirilerek).

Figure 1. Geological units and numerical distribution of rock-hewn storages in the Cappadocia Region (modified after Aydar et al., 2012).

Kaya oyma yapıların tasarımı noktasında bölgede tecrübeye dayalı bir yaklaşım kullanılmakta olup, uzun yıllardan bu yana yapılan bu kazılarda mühendislik hesaplamaları yeterli düzeyde dikkate alınmamıştır. Ancak, 18 Ekim 2017 tarihinde Resmi Gazete' de yayınlanan "Kayadan Oyma Yapıların Tasarım, Hesap ve Yapım Esaslarına Dair Yönetmelik” ile bölgede yapılacak yeni kaya oyma yapıların tasarımı ile ilgili önemli bir eksiklik giderilmeye çalışılmıştır. Yönetmelik 5 ana bölümden oluşmaktadır. Birinci bölümde; amaç, kapsam, dayanak ve çeşitli tanımlardan bahsedilmektedir. İkinci bölümde yönetmeliğin genel esasları sunulmuştur. Üçüncü bölümde; kaya parametrelerinin belirlenmesi amacıyla yürütülmesi gereken arazi incelemesi, yeraltı araştırmaları ve kaya kütle incelemeleri düzenleme esasları anlatılmıştır. 

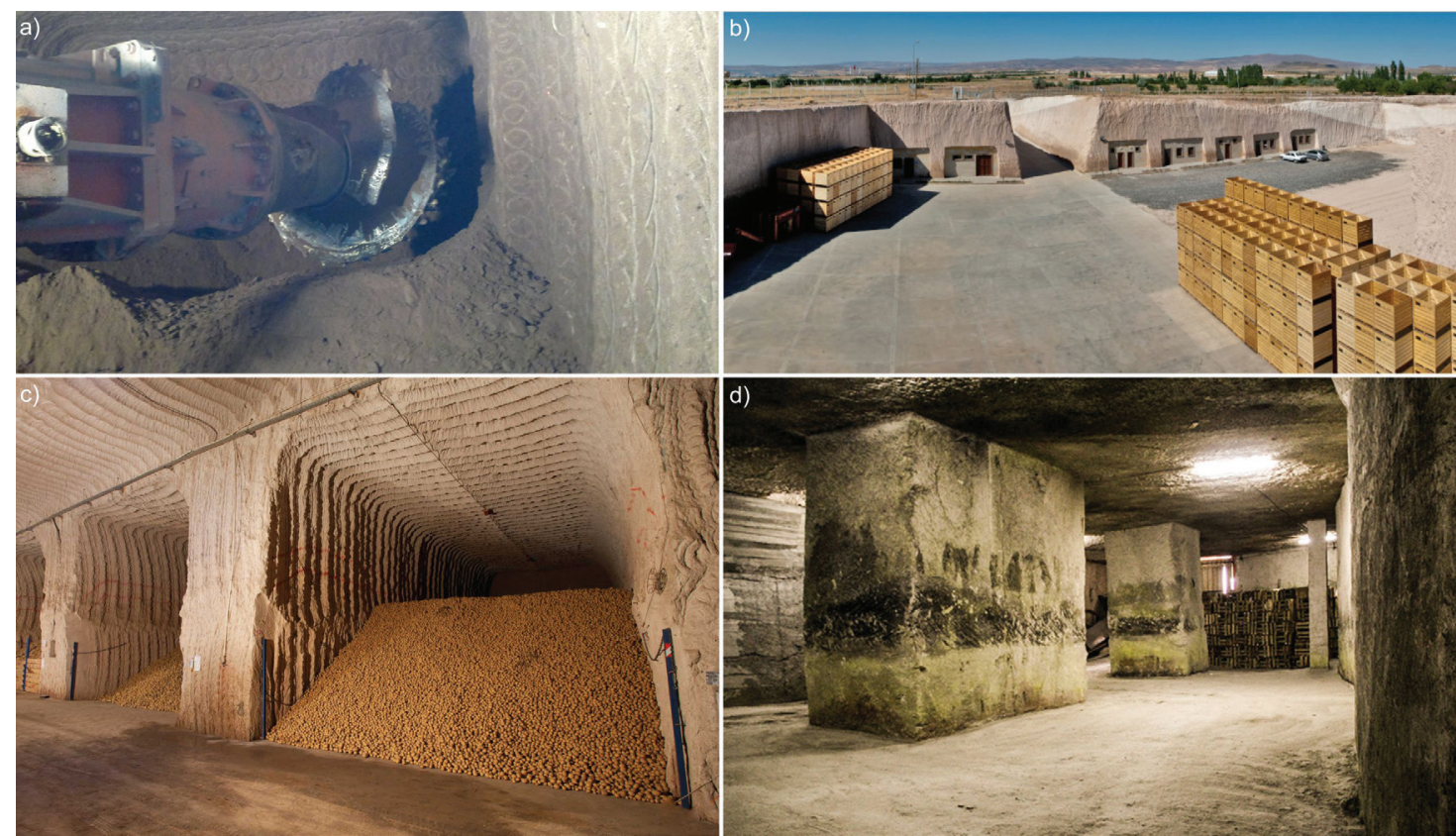

Şekil 2. Kaya oyma depolardan genel görünümler.

Figure 2. General views of the rock-hewn storages.

Dördüncü bölümde; tasarım ve projeler kapsamında uyulması gereken tasarım ilkeleri, yapısal esaslar, taşıyıcı sistemin analizi ve hesap kuralları, güçlendirme, mimari proje, yapı aplikasyon projesi, statik proje, mekanik tesisat projesi, elektrik tesisat projesi açıklanmaktadır. Beşinci ve son bölümde ise çeşitli ve son hükümler kapsamında geçiş hükümleri, mevcut başvurular, yapılar ve yürürlükten bahsedilmektedir. $\mathrm{Bu}$ yönetmelik sadece yeni kaya oyma yapılar için değil, mevcut kaya oyma yapıların yenilenmesi için de geçerlilik arz etmektedir. Söz konusu yönetmeliğin 12. maddesinde kaya oyma depolar ile ilgili olarak da genel bazı tasarım ölçütleri ortaya konulmuştur. Buna göre, en düşük örtü kalınlığının yapı genişliğinin yarısından az olmayacağı ve zayıf kayaçlarda ise örtü kalınlığının 5 metreden az olmaması gerektiği vurgulanmaktadır. Örtü kalınlığının 100 metreden fazla olduğu koşullarda kaya oyma deponun yapılamayacağı belirtilmiştir.
Bunun yanında, kaya oyma depolarda localar arasında bırakılacak ayak/topuk genişliğinin kaya kalitesine, süreksizlik yönelimine, kaya oyma yap1 genişliğine, loca genişliğine ve yüksekliğine bağlı olarak değiştiği Çizelge 1 'de verilen bir yaklaşım önerilmiştir. Söz konusu tasarım koşulları ağırlıklı olarak şimdiye kadar bölgede ve madencilik uygulamalarında edinilen tecrübelere dayanmaktadır. Bölgesel anlamda uygulanan yaklaşım göz önünde bulundurulmamış olup, günümüzde açılan kaya oyma depolarda loca genişliği 6 metre, ayak/ topuk genişliği 3 metre ve loca yüksekliği 6.5 metre olan bir mimari tasarım kullanılmaktadır. Bundan dolayı bu çalışmanın kapsamı ve amacı, söz konusu tasarım ölçütlerinin bölgesel anlamda uygulanabilirliğinin değerlendirilmesidir. $\mathrm{Bu}$ amaçla kurgulanacak farklı kaya depo modelleri üzerinde gerçekleştirilen sayısal analiz sonuçları değerlendirilecektir. 


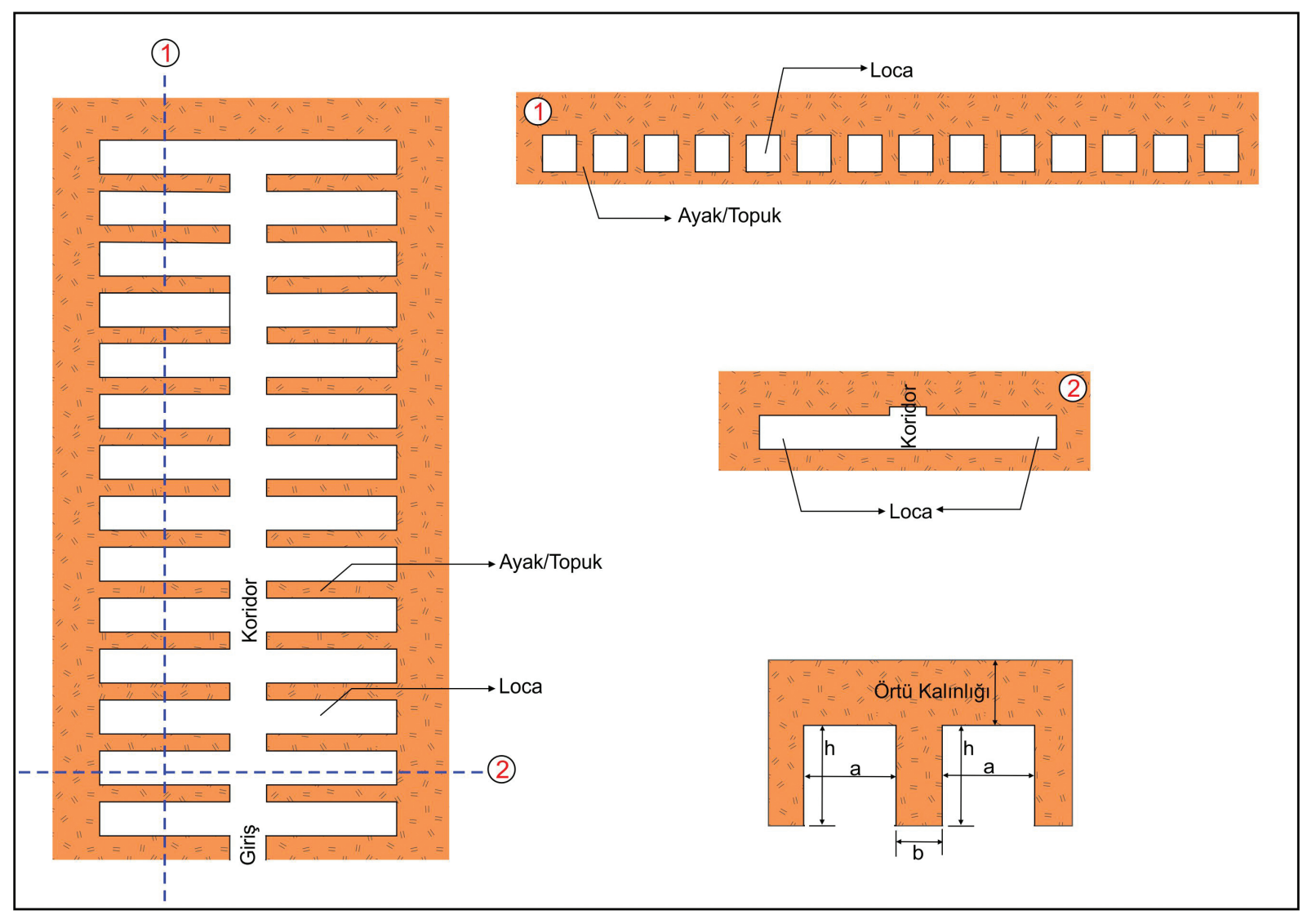

Şekil 3. Tipik bir kaya oyma deponun plan ve kesit görünümleri.

Figure 3. Plan and section views of a typical rock-hewn storage.

\section{Kaya Oyma Depoların Bulunduğu Bölgenin Jeolojik Yapısı}

Çalışmada özellikle Kapadokya Bölgesi’nde yer alan kaya oyma depolar göz önünde bulundurulmuş olup, söz konusu depolar Kapadokya Volkanik Kompleksi (KVK) içerisinde yer alan Neojen yaşlı piroklastik kayaçlar içerisinde açılmaktadır. Kapadokya Volkanik Kompleksi 40-60 km genişliğine ve 250 km'den daha fazla KD-GB yönünde uzanıma sahiptir (Toprak vd., 1994). Bu bölge güneyde Toros dağ kuşağı, kuzeyde Kırşehir masifi ve doğuda ve batıda Hasan Dağı ve Erciyes Dağ1 ile sınırlandırılmaktadır. Kapadokya Bölgesi’nin jeolojisi genel olarak temelde Neojen öncesi granitik kayaçlar, Neojen sedimanter kayaçlar, Neojen yaşlı volkano-sedimanter ve Kuvaterner yaşlı volkanik kayaçlardan oluşmaktadır. Bölgedeki Neojen-Kuvaterner volkanosedimanter istif ağırlıklı olarak ignimbiritlerden oluşmaktadır. Bölgedeki ignimbiritlerin stratigrafisi son olarak Aydar vd. (2012) tarafından güncellenmiş olup, yaşlıdan gence doğru ignimbiritler Kavak, Zelve, Sarımaden, Sofular, Cemilköy, Tahar, Gördeles, Kızılkaya, Valibaba ve Kumtepe olarak sınıflandırmıştır. 
Çizelge 1. Kaya oyma deponun kazı derinliği ve kaya kalitesine göre ayak/topuk genişliği (T.C. Resmi Gazete, 2017).

Table 1. Pillar width of rock-hewn storage based on excavation depth and rock quality (Republic of Turkey, Official Newspaper, 2017).

\begin{tabular}{cccc}
\hline \multirow{2}{*}{ Toplam Örtü Kalınlı̆̆1 } & \multicolumn{3}{c}{ Kayaç Sınıfi } \\
\cline { 2 - 4 } & Zayıf & Orta & Sağlam \\
\hline $0-50$ & $\frac{2 h}{5}<b<\frac{h}{2}$ & $\frac{h}{7}<b<\frac{h}{6}$ & $\frac{h}{8}<b<\frac{h}{7}$ \\
\hline $50-100$ & $b>h$ & $\frac{2 h}{5}<b<\frac{h}{2}$ & $\frac{h}{7}<b<\frac{h}{6}$ \\
\hline $100-150$ & $\frac{2 h}{3}<b<h$ & $\frac{2 h}{5}<b<\frac{h}{2}$ \\
& - & $\frac{2 a}{3}<b<a$ & $\frac{2 a}{5}<b<\frac{a}{2}$ \\
\hline $150-200$ & - & $b>h$ & $b>\frac{h}{2}$ \\
& & $b>a$ & - \\
\end{tabular}

Şekil 1'de verilen kaya oyma yapıların yayılımı göz önünde bulundurulduğunda, kaya oyma depoların ağırlıklı olarak Tmi olarak adlandırılan Miyosen ignimbiritleri içerisinde yer alan Üst Miyosen yaşlı Kavak ignimbiritleri içerisinde yer aldığı görülmektedir. Kavak ignimbiriti bazı kaynaklarda Ürgüp Formasyonu'nun, Kavak Üyesi olarak da tanımlanmaktadır (Temel, 1992; Toprak vd. 1994). Kavak Üyesi bölgede yaklaşı 2600 $\mathrm{km}^{2}$ 'lik bir alanda gözlenmekte olup, Ürgüp Formasyonu'nun en yaygın gözlenen üyesidir (Topal, 1995). Bundan dolayı bölgede yer alan birçok doğal, tarihi ve kültürel miras (peri bacaları, yeraltı şehirleri vb.) söz konusu birim içerisinde yer almaktadır. Kavak ignimbiritleri Kapadokya Volkanik Kompleksi'nde piroklastik çökellerin en yaşlısı olup, Aydar vd. (2012) tarafından Kavak-1, Kavak-2, Kavak-3 ve Kavak-4 olmak üzere dört alt birime ayrılmıştır. Kavak-1 seviyesi ters derecelenmiş pomzaca zengin bir görünüm sergilerken, Kavak-2 ise litik malzemeli volkanik külce zengin seviyeler ile temsil edilmektedir (Şekil 4). Kavak-3 pomzaca zengin birkaç seviyenin depolanmasıyla karakterizedir. Kavak-4 olarak adlandırılan ignimbirit seviyesi zengin kül matriks içerisinde pomza parçalı ve soluk pembe renkli piroklastik çökeller ile temsil edilmektedir (Aydar vd., 2012). Özet olarak, kaya oyma depolar geçmişte olduğu gibi günümüzde de ağırlıklı olarak Kavak ignimbiritlerinin farklı kaynaşma derecelerine sahip seviyeleri içerisinde açılmaktadır. 


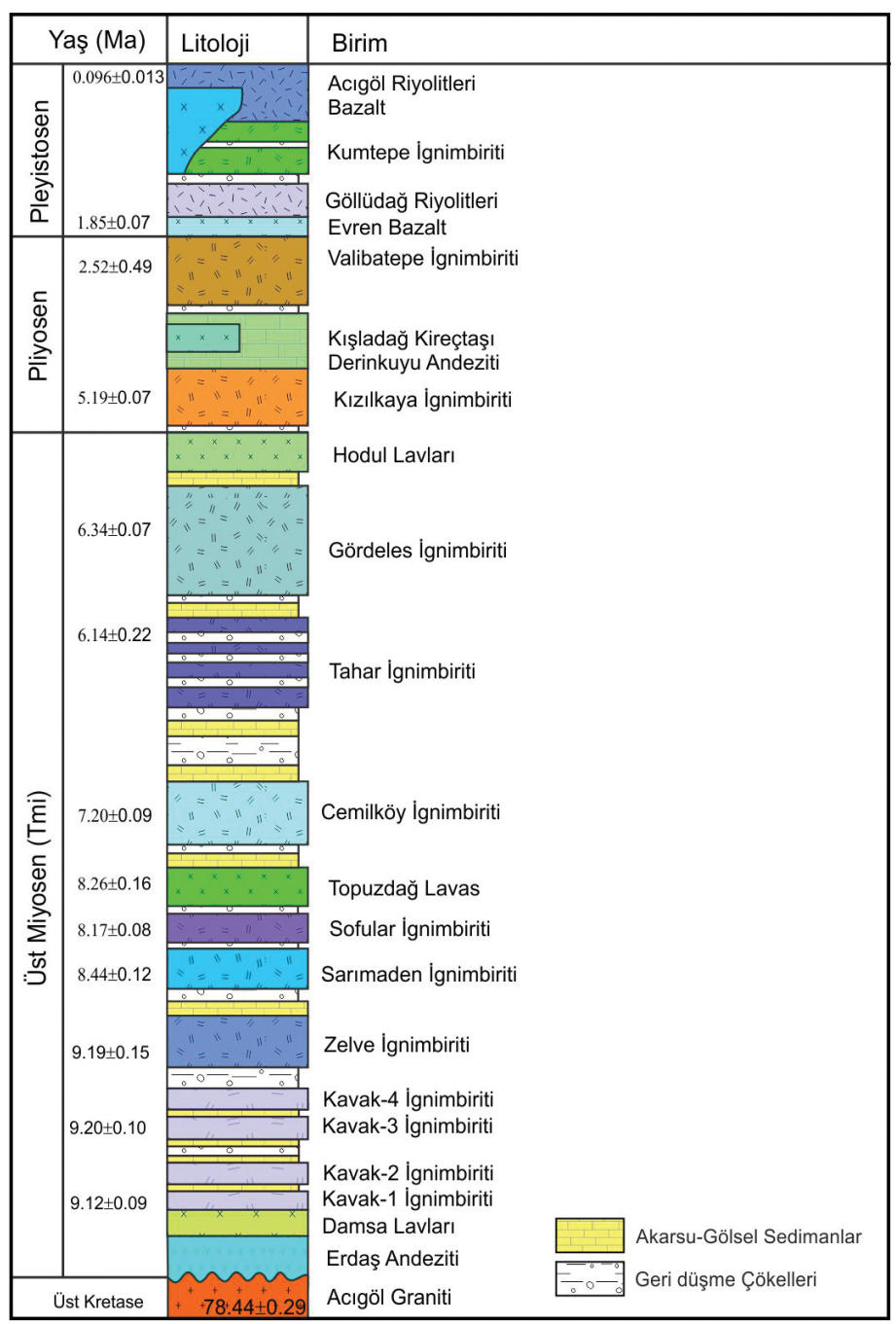

Şekil 4. Kapadokya bölgesinin genelleştirilmiş stratigrafik kesiti (Aydar vd., 2012'den değiştirilerek).

Figure 4. Generalized stratigraphic columnar section of the Cappadocia Region (modified after Aydar et al., 2012).

\section{MATERYAL VE YÖNTEM}

$\mathrm{Bu}$ çalışmada Kapadokya Bölgesi'nde ignimbiritler içerisinde son dönemde açılmış ve açılmakta olan kaya oyma depolarda kullanılan mimari tasarım boyutları sahip tipik bir örnek ve alternatif modeller üzerinden değerlendirilmiştir (Çizelge 2). Bu amaç için örnek olarak seçilmiş bir kaya oyma deposu sahasında blok örnek alımı için arazi, kaya malzeme özelliklerinin belirlenmesi için laboratuvar deneyi çalışmaları gerçekleştirilmiştir. Laboratuvar deneyleri Nevşehir Hacı Bektaş Veli Üniversitesi, Jeoloji Mühendisliği Bölümü, Zemin-Kaya Mekaniği Laboratuvarı'nda gerçekleştirilmiş olup, elde edilen sonuçlar Kavak ignimbiritlerinin literatürde yer alan malzeme özellikleri ile karşılaştırılarak bir veri aralığı oluşturulmuştur. Daha sonra, inceleme sahasındaki herhangi bir 
süreksizlik gözlenmeyen ignimbirit seviyelerinin kütlesel dayanım ve deformasyon özelliklerinin belirlenmesinde Hoek-Brown görgül yenilme ölçütünden (Hoek vd., 2002) yararlanılmıştır. Buna göre, ignimbirit kaya kütlesi için HoekBrown yenilme ölçütüne göre RocData (Rocscience, 2019b) yazılımı ile elde edilen eğrisel yenilme zarfina çizilen teğet yardımıyla Mohr-Coulomb yenilme parametreleri elde edilmiştir.

Bölgedeki kaya oyma depolarda genel mimari koridor ile koridorun sağında ve solunda yer alan yan yana localardan oluşmaktadır. $\mathrm{Bu}$ çalışmada 126 metre uzunluğunda, 6.5 metre genişliğinde ve 7.5 metre yüksekliğindeki koridor ile koridorun sağında ve solunda yer alan yan yana 14 locadan oluşan güncel mimariye uyan bir depo göz önünde bulundurulmuştur.
Localar 3 metre ayak/topuk genişliği ile oyulmuş 23 metre uzunluğunda, 6 metre genişliğinde ve 6.5 metre yüksekliğindedir. Örtü kalınlığg 12 metreye kadar ulaşmaktadır. Çalışma kapsamında söz konusu boyutlar göz önünde bulundurularak ayak/topuk genişliği, loca genişliği ve örtü kalınlığ değiştirilerek elde edilen mimari tasarım modellerinin gerilme ve toplam deformasyon davranışı sayısal analizler yardımıyla incelenmiştir. İncelenen modellerin özellikleri Çizelge 2'de verilmiş olup, sayısal analizlerde sonlu elemanlar yöntemine göre hesaplamalar yapan RS2 (Rocscience, 2019a) yazılımı kullanılmıștır. Analizler yardımıyla elde edilen sonuçlar üzerinde hassasiyet grafikleri oluşturularak bölgesel anlamda optimum tasarım ölçütleri önerilmiş ve mevcut yönetmelikte tanımlanan tasarım ölçütleri ile karşılaştırılmıştır.

Çizelge 2. Çalışmada kullanılan kaya oyma depo modelleri ve karakteristik özellikleri.

Table 2. Rock-hewn storage models considered in the study and their characteristic properties.

\begin{tabular}{ccccc}
\hline Model No & $\begin{array}{c}\text { Loca Genişliği } \\
(\mathrm{m})\end{array}$ & $\begin{array}{c}\text { Ayak/Topuk } \\
\text { Genişliği }(\mathrm{m})\end{array}$ & $\begin{array}{c}\text { Örtü Kalınlığ } \\
(\mathrm{m})\end{array}$ & Açıklamalar \\
\hline 01 & 6.0 & 3.0 & 12.0 & Genel mimari tasarım \\
02 & 6.0 & 0.5 & 12.0 & Ayak/Topuk Genişliği Değişimi \\
03 & 6.0 & 1.0 & 12.0 & Ayak/Topuk Genişliği Değişimi \\
04 & 6.0 & 2.0 & 12.0 & Ayak/Topuk Genişliği Değişimi \\
05 & 6.0 & 4.0 & 12.0 & Ayak/Topuk Genişliği Değişimi \\
06 & 7.0 & 3.0 & 12.0 & Loca Genişliği Değişimi \\
07 & 8.0 & 3.0 & 12.0 & Loca Genişliği Değişimi \\
08 & 9.0 & 3.0 & 12.0 & Loca Genişliği Değişimi \\
09 & 10.0 & 3.0 & 12.0 & Loca Genişliği Değişimi \\
10 & 11.0 & 3.0 & 12.0 & Loca Genişliği Değişimi \\
11 & 6.0 & 3.0 & 1.0 & Örtü Kalınlığı Değişimi \\
12 & 6.0 & 3.0 & 2.0 & Örtü Kalınlığı Değişimi \\
13 & 6.0 & 3.0 & 3.0 & Örtü Kalınlığı Değişimi \\
14 & 6.0 & 3.0 & 4.0 & Örtü Kalınlığı Değişimi \\
15 & 6.0 & 3.0 & 8.0 & Örtü Kalınlığı Değişimi \\
\hline
\end{tabular}




\section{Kaya Malzemesi ve Kaya Kütlesi Özellikleri}

Kaya oyma depoların temel kayası konumunda olan ignimbiritler Kapadokya Bölgesi'nde geniş alanlarda gözlenmektedir ve aynı zamanda bölgedeki doğal, tarihi ve kültürel miras söz konusu piroklastik kayaçlar içerisinde yer almaktadır. Bu özelliğinden dolayı bölgede yay1lım gösteren ignimbiritlerin fizikomekanik özellikleri birçok bilimsel çalışmaya konu olmuştur (Topal ve Doyuran 1995; Topal ve Doyuran 1997; Ulusay vd., 2006; Tuncay, 2009; Ulusay vd., 2013; Kaşmer ve Ulusay, 2013; Aydan ve Ulusay , 2013, Dinçer vd., 2016; Ulusay ve Aydan, 2018; Dinçer ve Bostanc1, 2019). Kaya oyma depoların genellikle içerisinde yer aldığı Kavak ignimbiritleri ağırlıklı olarak kirli beyaz renkte olup, yer yer pembemsi renkler de sunabilmektedir. Mineralojik olarak plajiyoklaz, kuvars, biyotit ve bazı opak mineraller içermektedir. Çeşitli kaya parçaları, pomza ve volkanik cam bileşenleri yaygın olarak gözlenmektedir. Kavak ignimbiritleri genel olarak yatay tabaklanma sunmakta olup, yüksek eğime sahip soğuma çatlakları ana süreksizlik tipi olarak tanımlanmıştır. Bu çalışmada, Kavak ignimbiritlerin bazı fiziksel ve mekanik özelliklerini belirlemeye yönelik bir dizi laboratuvar deneyleri ISRM (2007)'e göre gerçekleştirilmiştir. Örnekler Çat ve Nar bölgesinde açılmakta olan depo sahasından alınmıştır. Çalışma kapsamında elde edilen değerler ve Kavak ignimbiritleri için önceki çalışmalardan belirlenen değerler derlenerek Çizelge 3'de verilmiştir. Buna göre, Kavak ignimbiritleri çok düşük birim hacim ağırlıklı ve yüksek gözenekli kayaç olarak tanımlanmıştır (NBG, 1985). Deere ve Miller (1966)'ya göre çok düşük dayanımlı kaya sınıfında yer alan Kavak ignimbiritlerin tek eksenli basınç dayanımının genel olarak $10.00 \mathrm{MPa}$ 'dan düşük olduğu Çizelge 3'te açık bir şekilde görülmektedir.

Çizelge 3. Kavak ignimbiritlerinin bazı fiziksel ve mekanik özellikleri.

Table 3. Some physical and mechanical properties of the Kavak ignimbrites.

\begin{tabular}{|c|c|c|c|c|}
\hline Fiziksel ve Mekanik Özellikler & Ulusay vd. (2006) & $\begin{array}{l}\text { Tuncay } \\
(2009)\end{array}$ & $\begin{array}{c}\text { Topal (1995) } \\
\text { Topal ve } \\
\text { Doyuran (1997) }\end{array}$ & Bu Çalışma \\
\hline Birim Hacim Ağırlık $\left(\mathrm{kN} / \mathrm{m}^{3}\right)$ & $12.40-14.40$ & $13.30-14.30$ & $13.52-13.88$ & $14.58-15.64\left(6^{* *}\right)$ \\
\hline Gözeneklilik (\%) & - & $21-27$ & $37.48-38.73$ & $23.03-27.64\left(6^{* *}\right)$ \\
\hline P-Dalga Hızı (m/s) & $1236-2299(1672)$ & - & $1887-2190$ & - \\
\hline Ağırlıkça Su Emme (\%) & - & - & $29.28-29.90$ & $15.53-18.61\left(6^{* *}\right)$ \\
\hline Tek Eksenli Basınç Dayanımı (kuru) (MPa) & $2.30-9.10(4.6)^{*}$ & $3.60-5.00$ & $5.69-7.43$ & $4.23-7.99\left(5^{* *}\right)$ \\
\hline $\begin{array}{l}\text { Tek Eksenli Basınç Dayanımı (doygun) } \\
\text { (MPa) }\end{array}$ & - & $1.10-1.56$ & - & - \\
\hline Dolaylı Çekme Dayanımı (MPa) & $0.41-1.34(0.64)^{*}$ & - & $0.54-0.74(0.65)^{*}$ & - \\
\hline Elastisite Modülü (kuru) (GPa) & $0.20-2.34(1.1)^{*}$ & - & $2.80-4.20(3.08)^{*}$ & - \\
\hline Poisson Oranı (kuru) & - & - & $0.16-0.23(0.2)^{*}$ & - \\
\hline
\end{tabular}

* Ayraç içindeki değerler ortalama değerleri ifade etmektedir.

** Örnek Sayıs 
Bilindiği üzere kaya kütlelerinin dayanım ve deformasyon özellikleri kaya malzemesi dayanımı ve süreksizliklerin ortak bir fonksiyonudur. İnceleme sahasındaki ignimbiritlerin kaya malzemesi dayanımı laboratuvar deneyleri ile ortaya konmuştur. Öte yandan, çalışma sahasındaki ignimbiritler oldukça homojen bir yapı sergilemektedir. Kaya oyma depoların projelendirildiği sahada ignimbirit kütlesini kesen süreksizliklere rastlanmamıștır.

İgnimbirit seviyelerinin kütlesel dayanım ve deformasyon özelliklerinin belirlenmesinde Hoek-Brown görgül yenilme ölçütünden (Hoek vd., 2002) yararlanılmıştır. İgnimbirit kaya kütlesi için Hoek-Brown yenilme ölçütüne göre RocData yazılımı (Rocscience, 2019b) ile çizilen kaya kütlesi yenilme zarfi Şekil 5'te sunulmaktadır. Sayısal analizlerde, ignimbiritlerdeki homojen yapı göz önüne alınarak Mohr-Coulomb yenilme ölçütü dikkate alınmış olup, ignimbiritlerin makaslama dayanım parametreleri örtü yükü gerilmesi baz alınarak yenilme zarfına çizilen teğet yardımıyla belirlenmiştir. Öte yandan, yenilme zarfina bağlı olarak elde edilen kaya kütlesi dayanım parametreleri Çizelge 4'te özetlenmiştir.

İnceleme alanındaki ignimbiritlerin GSI puanı 80 olarak kabul edilmiştir. Buna göre, ignimbiritlerin, Hoek-Brown sabitleri olan "mb, s ve a" sirasiyla 7.34, 0.11 ve 0.50 olarak belirlenmiştir. $\mathrm{Bu}$ sabitlere göre ignimbirit kütlesinin çekme dayanımı $0.097 \mathrm{MPa}$, tek eksenli basınç dayanımı 2.16 $\mathrm{MPa}$, kütlesel dayanımı $2.84 \mathrm{MPa}$ ve deformasyon modülü $2021 \mathrm{MPa}$ olarak bulunmuştur. Bununla birlikte arazideki örtü yükü gerilmelerine bağl1 olarak eğrisel yenilme zarfına çizilen MohrCoulomb teğetine göre inceleme sahasindaki ignimbiritlerin kohezyon ve içsel sürtünme açıs1 değerleri $0.31 \mathrm{MPa}$ ve $57.5^{\circ}$ dir (Çizelge 4).

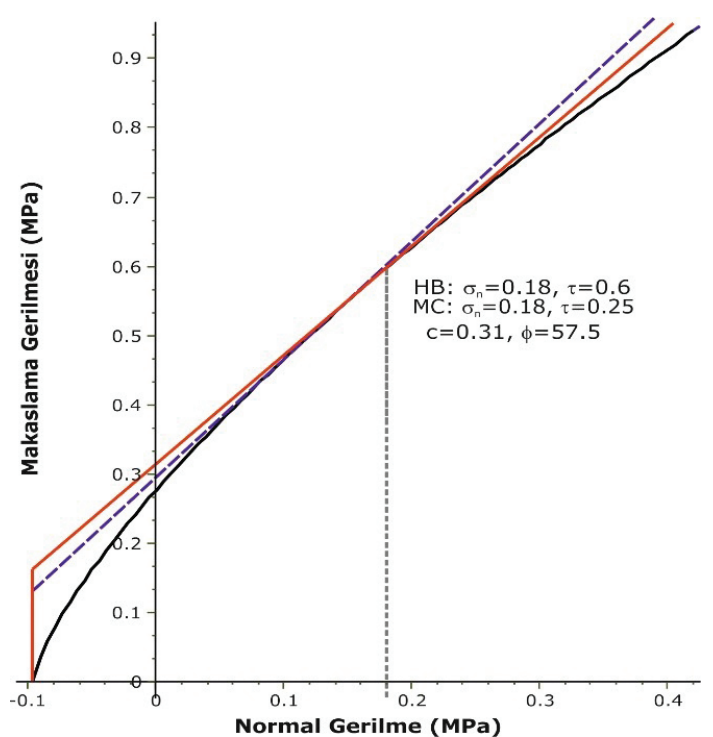

Şekil 5. İgnimbirit için Hoek-Brown yenilme ölçütüne göre hazırlanan eğrisel yenilme zarfı ve örtü yükü gerilmesine bağlı olarak çizilen Mohr-Coulomb teğeti.

Figure 5. Non-linear failure envelope of ignimbrite based on Hoek-Brown failure criterion and MohrCoulomb fit according to overburden stress.

\section{Loca Tavanlarında Oluşan Gerilme ve Deformasyonların Değerlendirilmesi}

Modellenen kaya oyma depoların sayısal analizi için iki boyutlu sonlu elemanlar yöntemine göre hesaplama yapan RS2 (Rocscience, 2019a) yazılımı kullanılmıştır. Analizlerde MohrCoulomb yenilme ölçütü dikkate alınmış olup, inceleme alanındaki ignimbiritlerin elasto-plastik davranış özelliği gösterdiği kabul edilmiştir. Analizlerde arazi gerilmeleri ve yerçekiminden kaynaklanan doğal kütle gerilmeleri göz önünde bulundurulmuştur. Girdi parametreleri olarak Çizelge 4'te verilen parametreler 1şı̆̆ında birim hacim ağırlık $15 \mathrm{kN} / \mathrm{m}^{3}$, elastisite modülü $2 \mathrm{GPa}$, Poisson oranı 0.30, çekme dayanımı $0.097 \mathrm{MPa}$, içsel sürtünme açısı $57^{\circ}$ ve kohezyon $0.31 \mathrm{MPa}$ olarak kabul edilmiştir. 
Çizelge 4. İnceleme alanındaki ignimbiritlerin HoekBrown yenilme ölçütüne bağlı olarak belirlenmiş dayanım ve deformasyon parametreleri.

Table 4. Strength and deformation parameters of the ignimbrites based on the Hoek-Brown failure criterion.

\begin{tabular}{|c|c|c|}
\hline \multicolumn{2}{|c|}{ UCS (MPa) } & 6.56 \\
\hline \multicolumn{2}{|c|}{ GSI } & 80 \\
\hline \multicolumn{2}{|c|}{$\mathrm{m}_{\mathrm{i}}$} & 15 \\
\hline \multicolumn{2}{|c|}{$\mathrm{D}$} & 0 \\
\hline \multicolumn{2}{|c|}{$\mathrm{E}_{\mathrm{m}}(\mathrm{MPa})$} & 2296 \\
\hline \multirow{3}{*}{$\begin{array}{l}\text { Hoek-Brown } \\
\text { sabitleri }\end{array}$} & $\mathrm{m}_{\mathrm{b}}$ & 7.34 \\
\hline & $\mathrm{s}$ & 0.11 \\
\hline & $\mathrm{a}$ & 0.50 \\
\hline \multirow{6}{*}{ 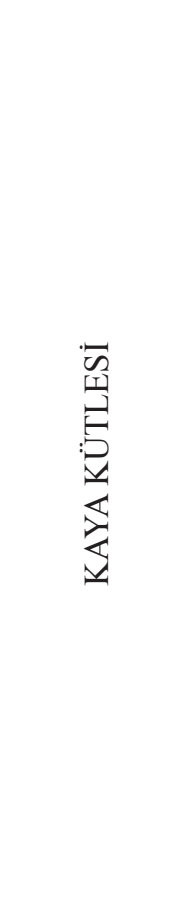 } & $\begin{array}{c}\text { Çekme } \\
\text { dayanımı } \\
(\mathrm{MPa})\end{array}$ & 0.097 \\
\hline & $\begin{array}{l}\text { Tek eksenli } \\
\text { basınç } \\
\text { dayanımı } \\
(\mathrm{MPa})\end{array}$ & 2.16 \\
\hline & $\begin{array}{l}\text { Kaya kütlesi } \\
\text { dayanımı } \\
(\mathrm{MPa})\end{array}$ & 2.84 \\
\hline & $\begin{array}{l}\text { Deformasyon } \\
\text { modülü (MPa) }\end{array}$ & 2021 \\
\hline & $\begin{array}{l}\text { Kohezyon* } \\
\text { (MPa) }\end{array}$ & 0.31 \\
\hline & $\begin{array}{l}\text { İçsel sürtünme } \\
\text { açı1sı }(\phi)^{*}\end{array}$ & 57.5 \\
\hline
\end{tabular}

*Doğrusal Mohr-Coulomb yenilme zarfi teğetine göre

Çalışma kapsamında genel mimari ile birlikte toplam 15 farklı model sayısal açıdan incelenmiş olup, Şekil 6'da kaya oyma depolarda genel olarak kullanılan boyutlar için sonlu elemanlar yönteminden elde edilen sonuçlar verilmiştir.
Genel mimariyi temsil eden kesit (Model-01), ayak/topuk performansını değerlendirmek için depo eksenine paralel olarak oluşturulmuş olup, yan yana 14 adet loca bulunmaktadir. Loca yüksekliği $6.5 \mathrm{~m}$, loca genişliği $6 \mathrm{~m}$, topuk genişliği $3 \mathrm{~m}$ ve depolar üzerinde yataya yakın bir topoğrafya izlenmekte olup, örtü kalınlığ1 12 m'dir. Sayısal analiz sonuçlarına göre, bu modelde maksimum gerilme değeri $1.00 \mathrm{MPa}$ iken, maksimum toplam deformasyon değeri $2.20 \mathrm{~mm}$ olarak hesaplanmıştır. Dayanım faktörü değerleri ise yapı boyunca duraylı koşulları işaret etmektedir.

Topuk genişliğinin kayadan oyma depoların tasarımına olan etkisini değerlendirmek üzere Model-2, Model-3, Model-4 ve Model-5'te verilen boyutlar göz önünde bulundurulmuştur. $\mathrm{Bu}$ durumda loca tavanlarının orta noktasındaki maksimum gerilme ve toplam deformasyon değişimi Şekil 7'de verilmiştir. Buna göre, topuk genişliğinin 4.0 metre olması durumunda loca tavanlarının orta noktasinda meydana gelen toplam deformasyon 1.2 ile $1.8 \mathrm{~mm}$ arasinda değişmekteiken, sadece 3 ve 12 numaralı localarda 1.7 ile $1.8 \mathrm{~mm}$ arasındadır. 4.0 metrelik topuk genişliğinde loca tavalarındaki deformasyon miktarlarında meydana gelen değişim homojen bir dağ1lım (sabit) göstermektedir. Buna karşın, topuk genişliğinin 0.5 m'ye kadar düşürülmesi her loca tavanında farklı değerlerin elde edilmesine neden olmuştur. $\mathrm{Bu}$ koşulda, loca sistemi içerisinde meydana gelen maksimum deformasyonlar orta bölümde yer alan localar (6-9 nolu) üzerinde yoğunlaşmıştır. Buna göre, 1 ve 14 numaralı localarda $3.0 \mathrm{~mm}$ civarında gerçekleşen toplam deformasyon miktarları, orta bölümde 8.3 mm'ye kadar yükselmiştir. Şekil 7a incelendiğinde eğrilerin yataya yakın ve dış bükey olmak üzere iki farklı eğilim sergiledikleri açık bir şekilde görülmektedir. 0.5 ve 1.0 metrelik topuk genişliklerinde $\mathrm{d}_{1}$ ş bükey bir eğilim egemen iken, 2.0, 3.0 ve 

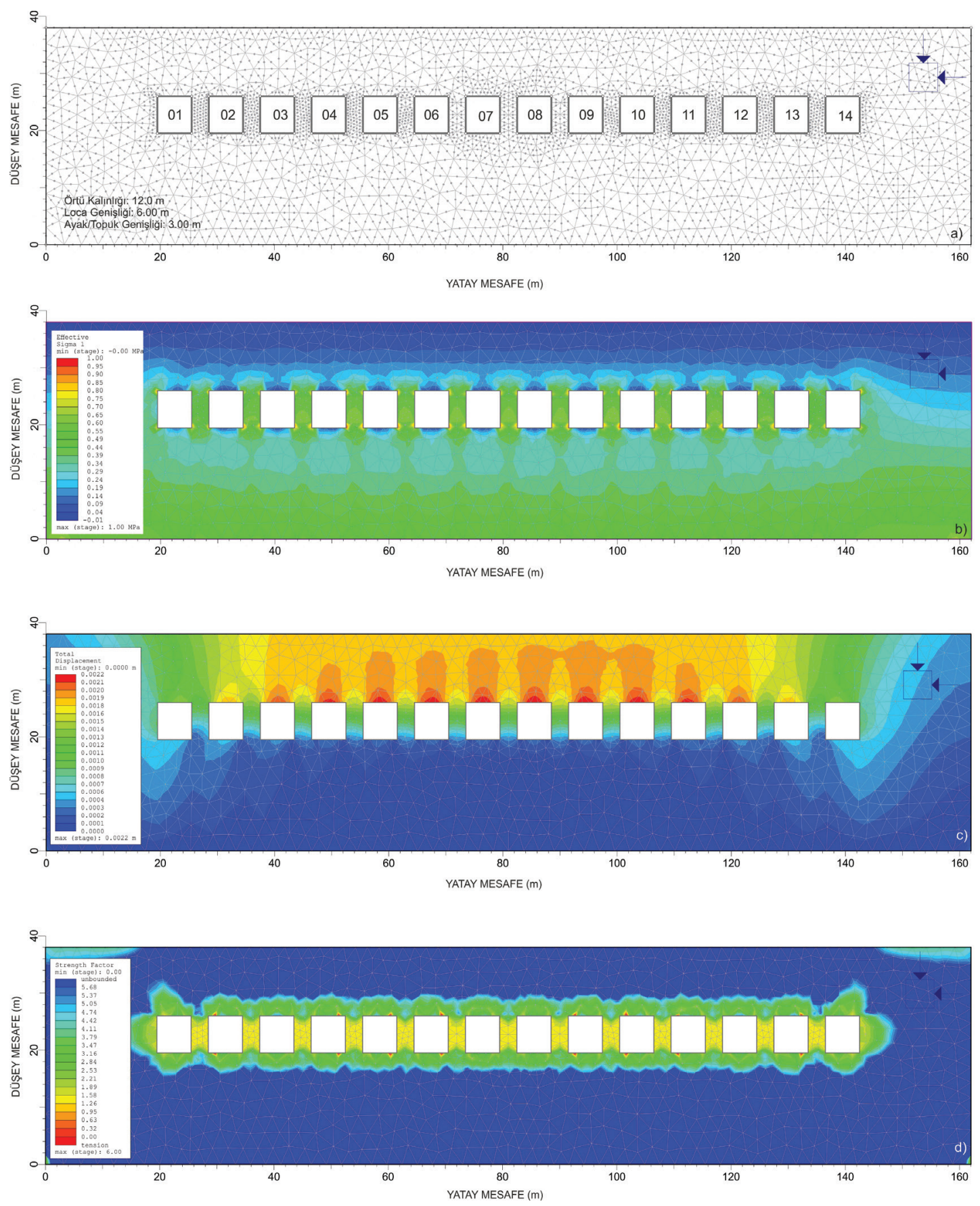

Şekil 6. Kaya oyma depolarda kullanılan genel mimarinin (Model-01) sonlu elemanlar analizi: a) ağ yapısı ve localar, b) efektif düşey gerilme $\left(\mathrm{s}_{1}\right)$, c) toplam deformasyon, d) dayanım faktörü dağılımları.

Figure 6. Finite element analysis of a typical rock-hewn storage design (Model-01): a) mesh structure and lodges, b) vertical effective stress $\left(\mathrm{s}_{1}\right)$, c) total deformation, d) strength factor distributions. 
4.0 metrelik topuk genişliklerinde toplam deformasyon değerleri yataya yakın bir görünüm sergilemektedir. Şekil 7b'de verilen efektif düşey gerilme değişimleri incelendiğinde ise 0.5 ve 1.0 metrelik topuk genişliğinde özellikle kenar locaların tavan bölümünde oluşan çekme gerilmeleri dikkati çekmektedir. Bunun yanında, toplam deformasyon değişiminde olduğu gibi 2.0 metreden yüksek topuk genişliklerinde 2 ile 13. localar arasında gerilme değerlerinin localar boyunca birbirine yakın değerler sergilediği dikkati çekmektedir. Bütün bu veriler birlikte değerlendirildiğinde, kaya oyma depoların tasarımı sırasında 2.0 metreden daha kalın topuk genişlikleri oluşturulması halinde loca sistemi içerisinde homojen bir gerilme ve deformasyon dağılımı gözlenmektedir. Öte yandan, 2.0 metreden daha dar ayak genişliklerinde ise gerilme ve deformasyon açısından daha değişken koşullar oluşmakta ve özellikle orta bölümde yer alan localarda görece yüksek deformasyonların gözlenmesine neden olmaktadır. Buna göre, kayadan oyma depolarda 2.0 metrelik topuk genişliği optimum değer olarak değerlendirilebilir.

Bölgede son dönemde açılan birçok kayadan oyma depoda loca genişliği genel olarak $6 \mathrm{~m}$ olarak planlanmaktadır. Loca genişliğinin etkisini araştırmak üzere Model 6, 7, 8,9 ve 11 'deki $6,7,8,9,10$ ve 11 metrelik loca genişlikleri değerlendirilmiştir. Loca tavanlarının orta bölümünde elde edilen toplam deformasyon ve maksimum gerilme grafikleri Şekil 8'de verilmiştir. Buna göre, loca genişliğinin artmasına bağlı olarak deformasyon değerleri düzenli bir şekilde artmakta ve başlangıç locaları hariç localar boyunca genelde yatay bir değer dağ 11 ımı gözlenmektedir. Beklenildiği gibi en düşük deformasyon değerleri 6 metrelik loca genişliği için elde edilmiş olup, maksimum deformasyon miktarları 1.3 ile $2.1 \mathrm{~mm}$ arasında değişmektedir.
Loca genişliğinin 11 m’ye ulaşması durumunda deformasyon miktarları $4 \mathrm{~mm}$ 'yiaşmaktadır. Loca tavanlarının orta bölümünde oluşan maksimum gerilme loca genişliğine bağlı olarak azalmakta fakat kenarlarda yer alan loca tavanlarında bir miktar çekme gerilmeleri oluşmaktadır. Bu koşullarda maksimum gerilmeler orta bölümde yer alan locaların köşelerinde yoğunlaşmaktadır.

Kayadan oyma depoların tasarımında diğer önemli husus kazı üzerindeki optimum örtü kalınlığının belirlenmesidir. $\mathrm{Bu}$ amaçla çalışmada $1 \mathrm{~m}$ ile $12 \mathrm{~m}$ arasında değişen altı farklı örtü kalınlığ koşulu değerlendirilmiş ve loca tavanlarının orta bölümünde elde edilen maksimum deformasyon gerilme grafikleri Şekil 9'da verilmiştir. Topuk genişliğinde olduğu gibi, elde edilen grafiklerde iki farklı eğilim gözlenmektedir. Meydana gelen toplam deformasyonlar açısından bakıldığında 12 ve 8 metrelik örtü kalınlıklarında beklenildiği gibi örtü kalınlığının fazla olmasına bağlı olarak daha yüksek deformasyon değerleri elde edilmiştir. 1 ile $4 \mathrm{~m}$ arasında değişen örtü kalınlıklarında ise locaların tamamında yatay eğilimli ve $1 \mathrm{~mm}$ 'den küçük deformasyon değerleri elde edilmiştir. Örtü kalınlığının meydana gelen düşey gerilmeler üzerine olan etkisi incelendiğinde ise dikkat çekici sonuçlar elde edilmiştir. Yine beklenildiği gibi yüksek örtü kalınlıklarında daha yüksek gerilmeler elde edilmiştir. Fakat örtü kalınlığının azalmasıla birlikte loca tavanlarında çekme gerilmeleri oluşmaya başlamıştır. Özellikle 2 ve 3 metrelik örtü kalınlıklarında locaların tamamına yakın bir bölümünün tavanlarında çekme gerilmeleri oluşmaktadır. 1 metrelik örtü kalınlığı ise düşük örtü yükünden dolay1 çekme gerilmeleri oluşturmazken, 4 metrelik örtü kalınlığında loca tavanlarındaki çekme gerilmeleri tamamen ortadan kalkmaktadir. Bundan dolayı örtü kalınlığı açısından 4 metrelik kalınlık optimum değer olarak kabul edilebilir. 

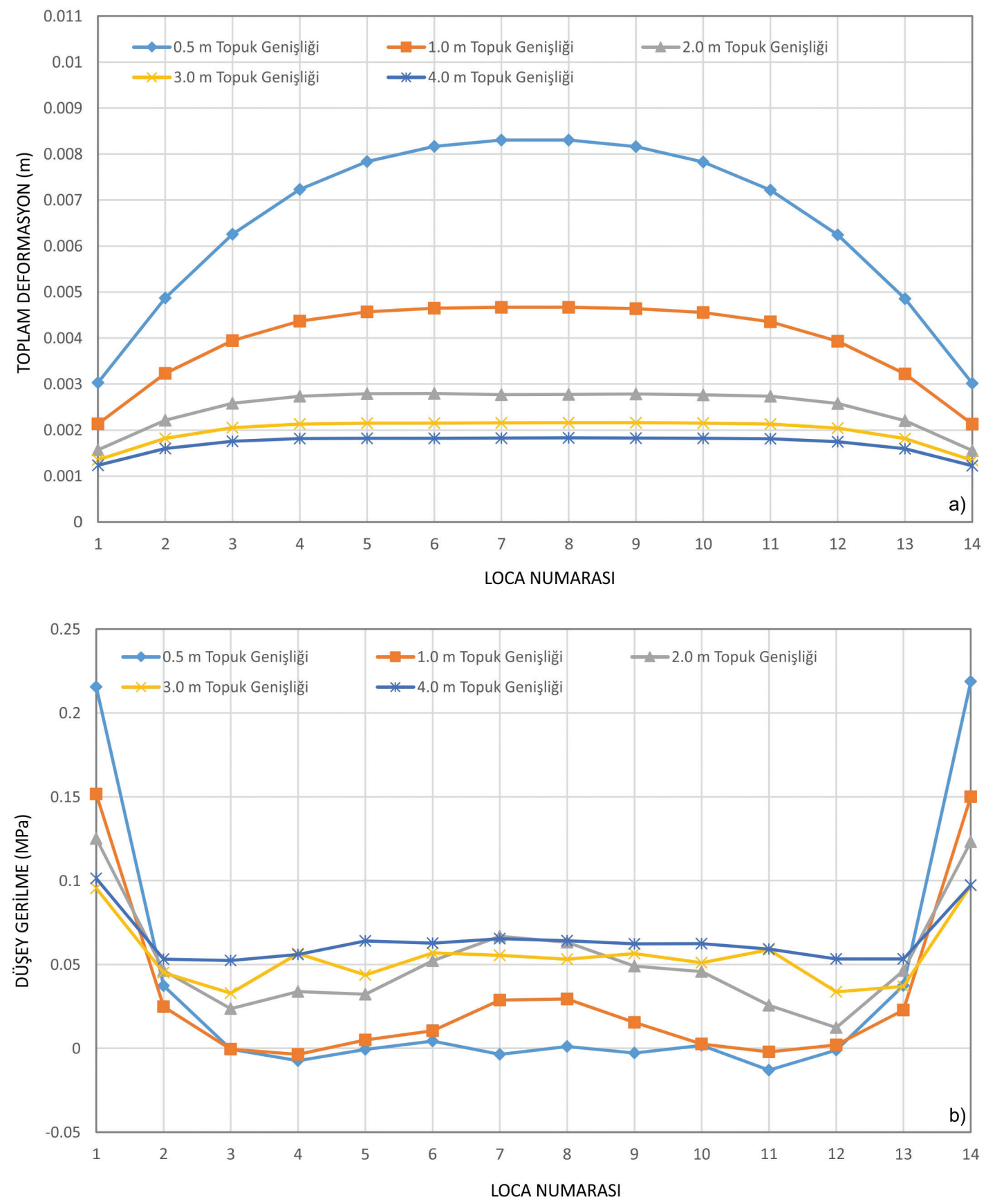

Şekil 7. Topuk genişliği değişimine göre loca tavanlarının orta noktasında meydana gelen maksimum gerilme ve toplam deformasyon değişimi.

Figure 7. Variation of maximum stress and deformation in the middle section of the lodge roof based on pillar width variation. 

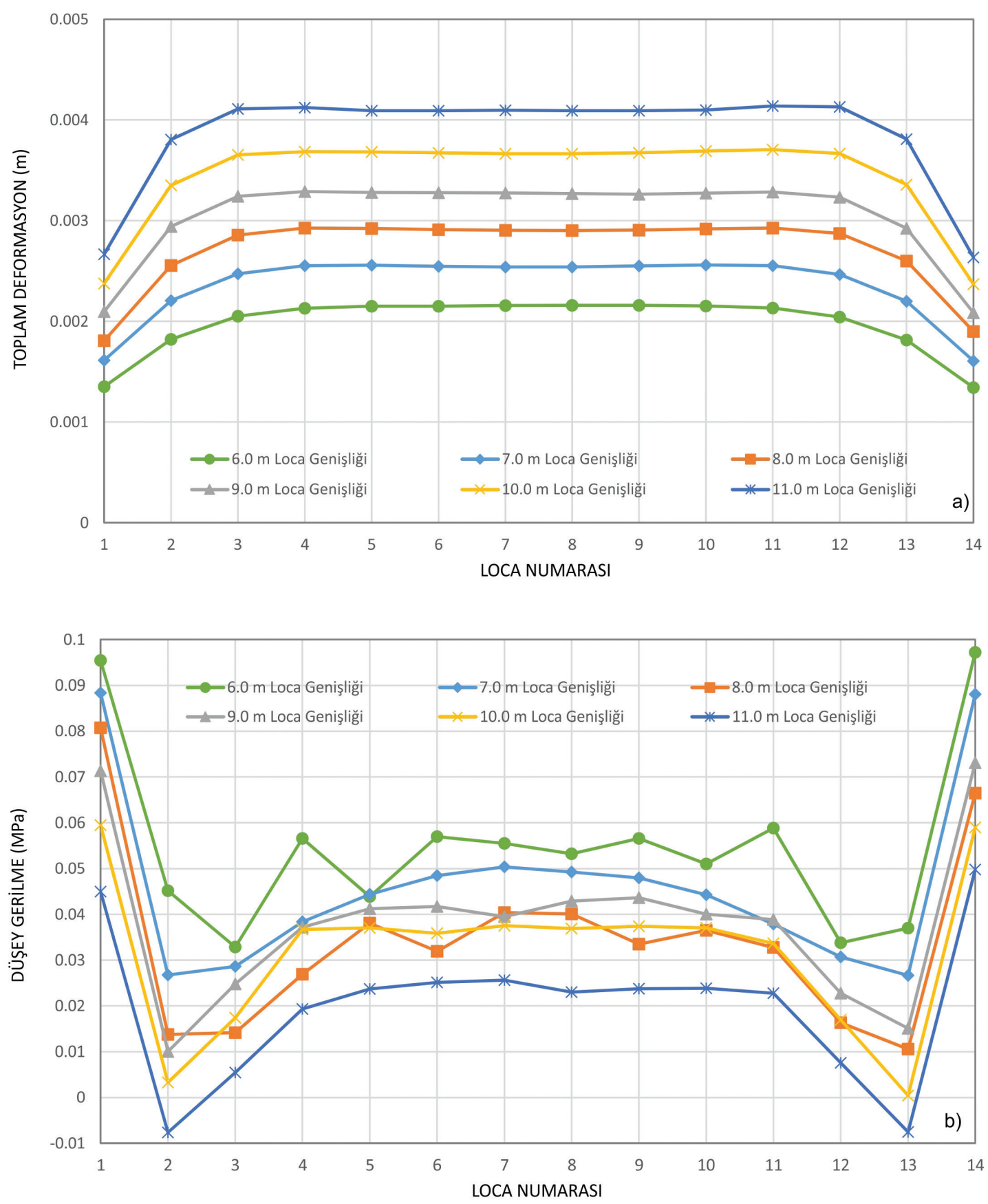

Şekil 8. Loca genişliği değişimine göre loca tavanlarının orta noktasında meydana gelen gerilme ve deformasyon değişimi.

Figure 8. Variation of maximum stress and deformation in the middle section of the lodge roof based on lodge width variation. 

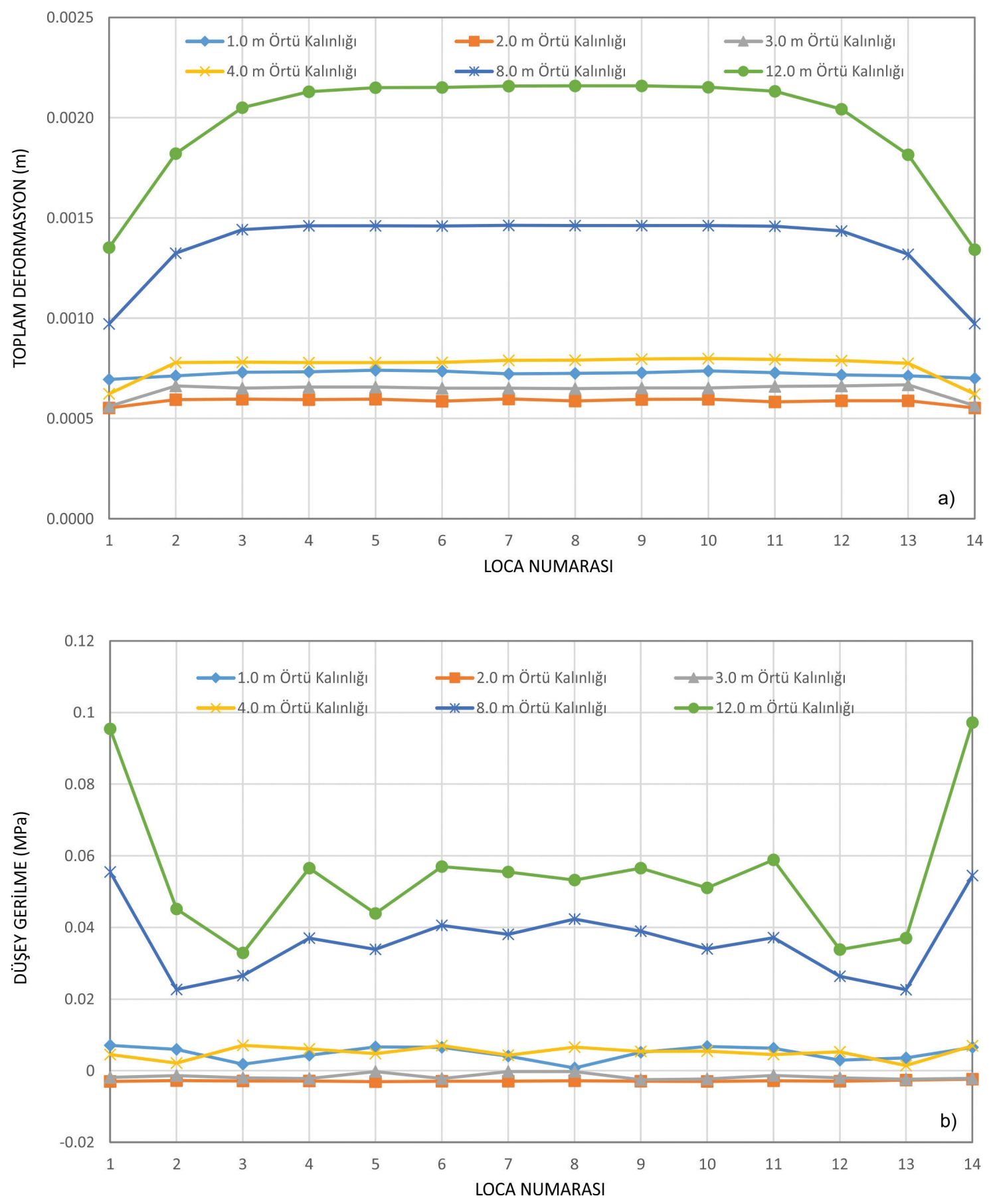

Şekil 9. Örtü kalınlığı değişimine göre loca tavanlarının orta noktasında meydana gelen gerilme ve deformasyon değişimi.

Figure 9. Variation of maximum stress and deformation in the middle section of the lodge roof based on overburden thickness variation. 


\section{Model Genelinde Oluşan Gerilme ve Deformasyonların Değerlendirilmesi}

$\mathrm{Bu}$ çalışmada farklı loca genişliği, topuk genişliği ve örtü kalınlığı gibi bazı tasarım ölçütleri için kaya oyma depoların jeomühendislik performansı sayısal analizler yardımıyla değerlendirilmiştir. Söz konusu farklı tasarım ölçütlerinde locaların tavan ortalarında oluşan maksimum düşey efektif gerilme ve toplam deformasyon değerleri önceki bölümde değerlendirilmiş olup, bu bölümde değerlendirilen modeller bünyesinde elde edilen maksimum düşey gerilme ve maksimum toplam deformasyon değişimleri değerlendirilmiştir (Şekil 10). Diğer bir ifadeyle, incelenen modelin herhangi bir noktasında elde edilen en yüksek değer bu bölümdeki değerlendirme kapsamında dikkate alınmıştır. Buna göre, Şekil 10a'da farklı topuk genişliklerinde modelin genelinde elde edilen maksimum düşey gerilme ve maksimum toplam deformasyon değerleri verilmiş olup, topuk genişliğinin artmasıyla birlikte gerilme ve deformasyon değerleri azalmaktadır. 2 metrelik topuk genişliğine kadar gerilme ve deformasyon değerlerindeki azalma oldukça sert bir şekilde gerçekleşirken, 2 metreden daha büyük topuk genişliklerinde bu değerlerdeki azalma daha düşük bir şekilde gerçekleşmektedir. Topuk genişliğinin 2 metreden daha az olduğu koşullarda ise maksimum gerilmeler topuklar üzerinde yoğunlaşmaktadır. Buradan açık bir şekilde görülmektedir ki, mevcut koşullarda topuk genişliklerinin 2 metreden kalın olmasının sistemin duraylılığına ilave bir katkısı bulunmadığı gibi, gereğinden fazla birakılacak topuk genişlikleri kaya oyma depolarda depolama kapasitesinin azalmasina neden olabilmektedir.
Şekil 10b'de loca genişliğinin gerilme ve deformasyon üzerindeki etkisi değerlendirilmiş olup, loca genişliğinin artışıyla, beklenildiği gibi maksimum düşey gerilme ve toplam deformasyon artmıştır. Loca genişliğinin 6 metreden 7 metreye çıkarılması, gerilme ve deformasyon değerlerinde ciddi bir değişikliğe neden olmamıştır. Ancak 7 metreden sonra gerilme ve deformasyon miktarlarındaki düzenli artış daha net bir şekilde gözlenmektedir.

2017 yılında çıkarılan "Kayadan Oyma Yapıların Tasarım, Hesap ve Yapım Esaslarına Dair Yönetmeliğin 12 maddesi 1(a) fikrasında örtü kalınlığı ile ilgili şu ifade yer almaktadır: “depo amaçlı kayadan oyma yapılar için minumum örtü kaya kalınlığg kayadan oyma yap1 (açıklığın) genişliğinin yarısından az olamaz ve zayıf kayalarda örtü kaya kalınlığının en az 5 metre olması gerekir". Şekil 10c'den görüleceği üzere 4 metrelik örtü kalınlığına kadar gerilme de deformasyon eğrilerindeki artış yataya yakın bir şekilde gözlenirken, 4 metreden daha fazla olan örtü kalınlıklarında gerilme ve deformasyon artışı daha yüksek olmaktadır. Burada dikkat edilmesi gereken esas konu, basınç gerilmesi artışından ziyade örtü kalınlığının az olması durumunda loca tavanlarında oluşan çekme gerilmeleridir. Şekil 9'dan da açık bir şekilde görüleceği üzere örtü kalınlığının 4 metrenin altında olması durumunda loca tavanlarında çekme gerilmeleri oluşmakta ve bu durum kaya oyma yapının duraylılığını olumsuz yönde etkileyebilmektedir. $\mathrm{Bu}$ değerlendirmeler 1şı̆̆ında, kaya oyma depolarda localar üzerindeki optimum örtü kalınlığı 4 metre civarında olmalıdır. Bu durum, 2017 yılında yayınlanan yönetmelikle büyük ölçüde uyum göstermektedir. 

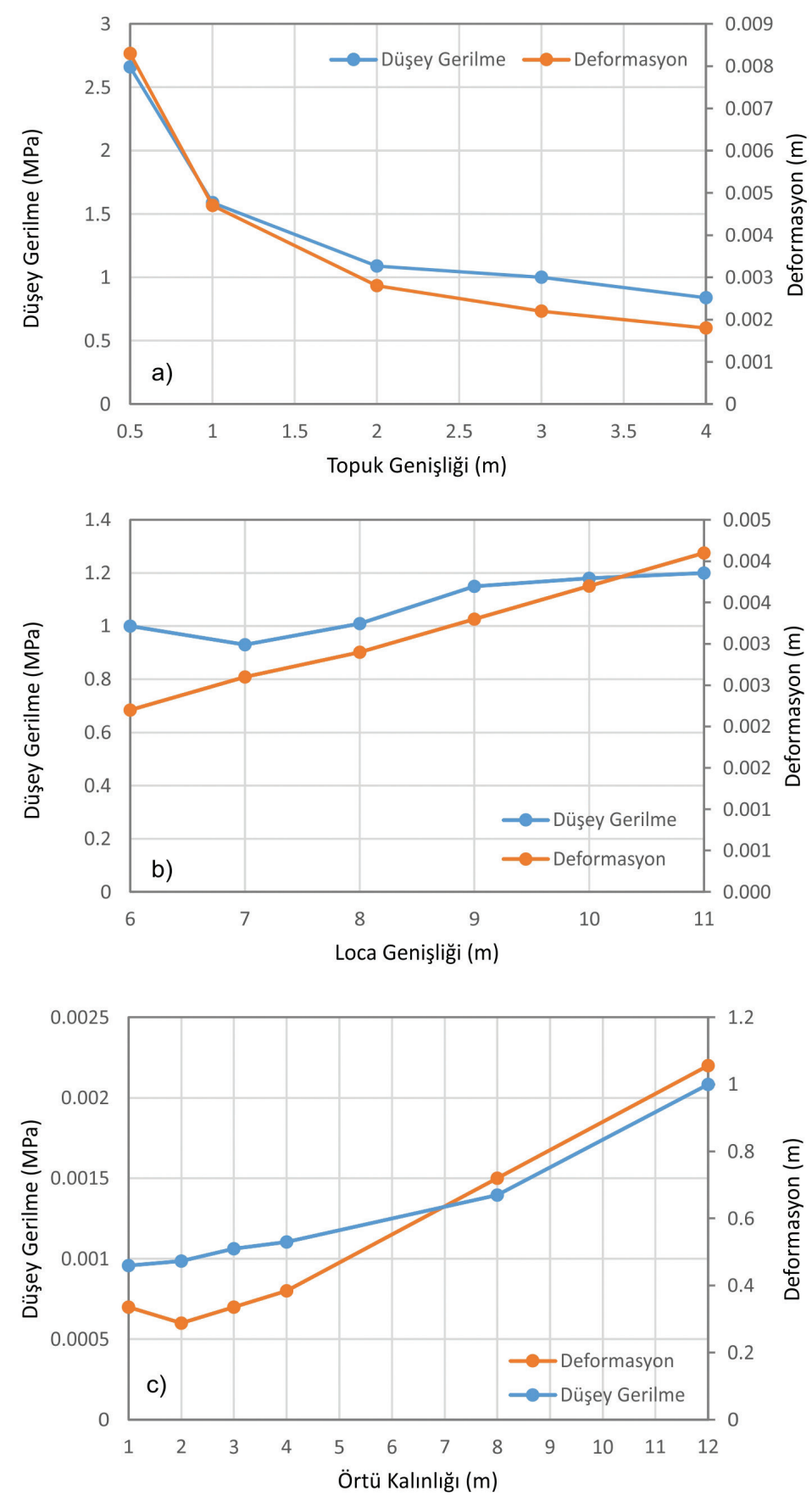

Şekil 10. Modellerde meydana gelen maksimum gerilme ve deformasyon miktarlarının farklı koşullara göre değiş̧imi a) topuk genişliği, b) loca genişliği, c) örtü kalınlığı.

Figure 10. Variation of maximum stress and deformation values in the models based on different parameters, a) pillar width, b) lodge width, c) overburden thickness. 


\section{Kaya Oyma Depo Boyutlarının Mevcut Yönetmelik ve Farklı Tasarım Ölçütleri Doğrultusunda Değerlendirilmesi}

Kapadokya bölgesinde açılan ve açılmakta olan kayadan oyma depoların genelinde, bu çalışmada göz önünde bulundurulduğu gibi 3 metrelik topuk genişliği yaygın olarak tercih edilmektedir. Topuk genişliğinin tasarımı noktasında 2017 yılında çıkan yönetmeliğin 12 maddesi 1(c) fikrasında belirtilen ve Çizelge 1'de verilen tasarım ölçütleri tanımlanmıştır. $\mathrm{Bu}$ çalışmada göz önünde bulundurulan kaya oyma depo projesinde örtü kalınlığı 12.0 m olup, localar $6 \mathrm{~m}$ genişliğinde, $6.5 \mathrm{~m}$ yüksekliğinde, 23 metre uzunluğundadır. Localar arasında 3 $\mathrm{m}$ genişliğinde topuklar mevcuttur. Söz konusu proje için topuk genişliğinin Çizelge 1'de ve denklem (1)'de verilen koşula göre 2.60 ile 3.25 metre arasinda olmas1 gerekmektedir. Projede bu koşullar sağlanmış ve herhangi bir duraysızlık problemi yaşanmadan proje tamamlanmıştır.

$$
\frac{2 h}{5}<b<\frac{h}{2}
$$

Bilindiği üzere oda-topuk yöntemi madencilikte yaygın olarak kullanılan bir üretim şekli olup, yöntemin esası güvenli topuk boyutlarının belirlenmesine dayanmaktadır. Mark (2006), ilk topuk tasarımlarının 1773 yılında Coulomb tarafından yapıldığını belirtmiş olup, daha sonra birçok bilimsel temele dayanan topuk tasarımları geliştirilmiştir (Salamon ve Munro, 1967; Obert ve Duvall, 1967; Logie ve Matheson, 1982; Bieniawski, 1992; Merve, 2003; Ren vd., 2020). Bu yaklaşımlarda topuğun taşıma kapasitesinin belirlenmesinde topuk üzerine gelecek yüke oranlanarak elde edilecek güvenlik katsayısı üzerinden değerlendirmeler yapılmaktadır. $\mathrm{Bu}$ çalışmada elde edilen sonuçları ve yönetmelikte geçerli olan koşulları karşılaştırmak için Bieniawski (1992) tarafından önerilen genel/temel yaklaşım göz önünde bulundurulmuştur.

$$
S_{p}=\sigma_{c}\left[0.64+0.36\left(\frac{w_{p}}{h}\right)\right]^{\alpha}
$$

Burada $\alpha$ sabit sayı (topuğun genişlikyükseklik oranına göre belirlenmekte olup, genişlik-yükseklik oranı 5 'den büyük ise 1.4, 5'den küçük ise 1.0 olarak alınır); $S p$ topuğun basınç dayanımı (MPa); $W p$ topuk genişliği (m); $h$ topuk yüksekliği (m); $\sigma_{c}$ tek eksenli basınç dayanımını (kütle, MPa) ifade etmektedir. Topuğun üzerine gelecek yük topuk madenciliğinde yaygın olarak kullanılan eş yüklü alan (tributary area) yöntemi kullanılarak belirlenmiştir (Yavuz, 2001)

$C_{p}=\gamma \cdot H\left[\frac{w_{p}+w_{e}}{w_{e}}\right]$

Burada $W p$ topuk genişliği (m); We loca genişliği (m); H örtü kalınlığı (m) ve $\gamma$ kaya birim hacim ağırlığını $\left(\mathrm{MN} / \mathrm{m}^{3}\right)$ ifade etmektedir. Topuğun duraylılı̆̆ının kontrolü için güvenlik katsayısı (Gs) aşağıdaki formül ile tanımlanmaktadır. Asgari güvenlik katsayısının 1.5 ile 2.0 arasinda olması istenmekte olup, Bieniawski (1992) kısa süreli topuk tasarımında 1.5 , kaya oyma depolar gibi uzun süreli topuk tasarımlarında ise 2.0 alınmasını önermiştir.

$G_{s}=\frac{s_{p}}{C_{p}}$

$\mathrm{Bu}$ çalışmada göz önünde bulundurulan kayadan oyma deponun mevcut projesi (12 m örtü kalınlığ, $6 \mathrm{~m}$ loca genişliği, $6.5 \mathrm{~m}$ loca yüksekliği, $23 \mathrm{~m}$ loca uzunluğu, localar arası 3 $\mathrm{m}$ topuk genişliği) Bieniawski (1992) yöntemine göre değerlendirilmiştir. Buna göre, topuğa gelecek gerilme ve topuğun dayanımı sırasıyla $0.54 \mathrm{MPa}$ ve $2.29 \mathrm{MPa}$ olarak hesaplanmış olup, güvenlik katsayısı 4.24'dür. Buna göre 
3 metrelik topuk genişliği istenen güvenlik katsayısı koşullarını fazlasıyla karşılamaktadır.

Bölgede kaya oyma depoların yapım koşulları incelendiğinde kaya dayanımı, kaya birim hacim ağırlığı ve loca genişlikleri çok fazla değişkenlik göstermezken, topoğrafik ve morfolojik koşullardan dolayı örtü kalınlığ1 bölgesel anlamda farklılık sunabilmektedir. Bundan dolayı topuk genişliğinin örtü kalınlığına karşı hassasiyetini ortaya koymak için farklı topuk genişlikleri için farklı örtü kalınlıklarının (0-100 m) sunacağı güvenlik katsayısı değerleri yukarıda belirtilen yaklaşım ile belirlenmiş ve elde edilen sonuçlar Şekil 11'de verilmiştir. Şekil 11'de görüleceği üzere topuk genişliği örtü kalınlığına karşı hassasiyet göstermektedir. Asgari güvenlik katsayısı olarak 2 göz önünde bulundurulduğunda 3 metrelik topuk genişliği yaklaşık 25 metrelik örtü kalınlığına kadar asgari koşulları sağlamaktadır. Yine 2 metrelik topuk genişliği 17 metrelik örtü kalınlığına kadar asgari koşulları sağlamaktadır. Bu durum, Şekil 10a'da verilen grafik ile uyumluluk göstermektedir. Güvenlik katsayısının 2 olduğu durumda seçilen her bir loca genişliğine karşılık gelen örtü kalınlıkları karşılaştırıldığında korelasyon katsayısı (R) 0.99 olan doğrusal bir ilişki $(y=7.5 x+1.9)$ elde edilmiştir (Şekil 12). Bu ilişki bölgesel anlamda topuk tasarımında göz önünde bulundurulabilir.

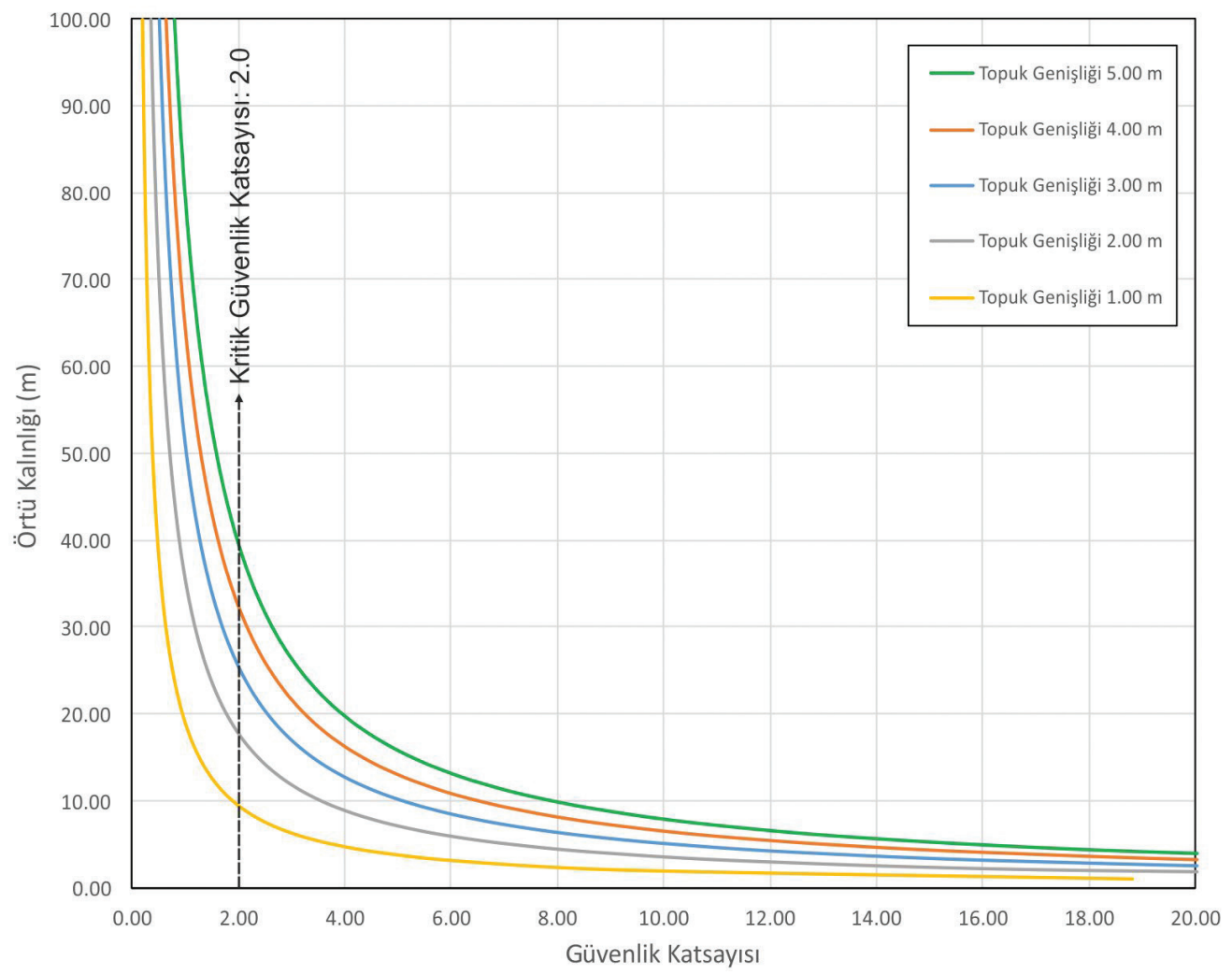

Şekil 11. Farklı topuk genişliklerinde güvenlik katsayısının örtü kalınlığına göre değişimi.

Figure 11. Safety factor variation at different pillar width with respect to overburden thickness. 


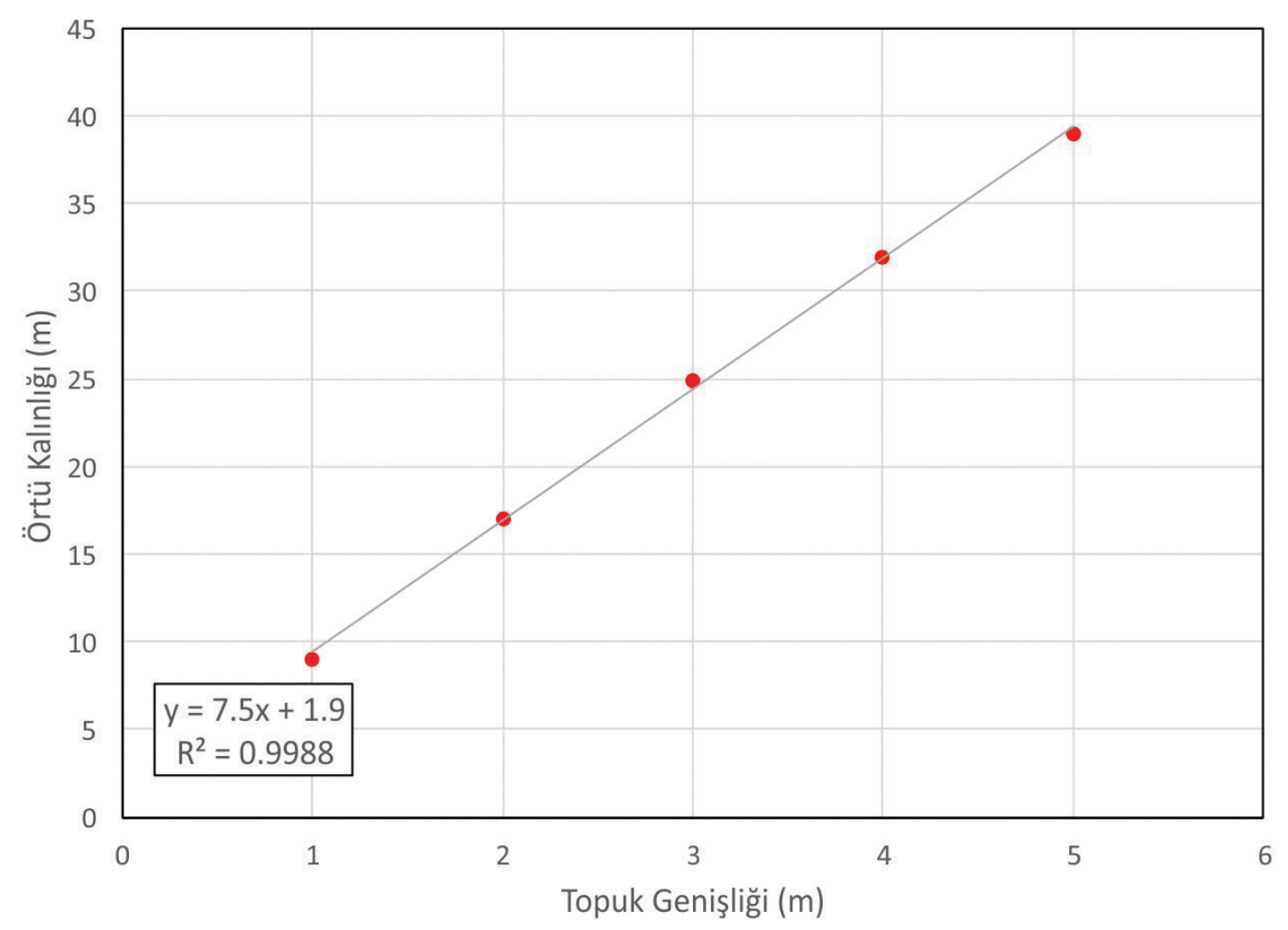

Şekil 12. Topuk genişliği ve örtü kalınlığı arasındaki ilişki.

Figure 12. Relationship between pillar width and overburden thickness.

\section{SONUÇLAR}

Kapadokya'nın önemli ekonomik değerleri arasında yer alan kayadan oyma depolar, 2017 yılına kadar bölgesel anlamda elde edilmiş olan tecrübe 1şığında açılmıştır. Ancak, 18 Ekim 2017 tarihinde çıkarılan "Kayadan Oyma Yapıların Tasarım, Hesap ve Yapım Esaslarına Dair Yönetmelik" ile bölgede yapılacak yeni kaya oyma yapıların tasarımı ile ilgili önemli bir eksiklik giderilmeye çalışılmıştır. İlgili yönetmeliğin 12-1 maddesinde kaya oyma depoların bazı tasarım ölçütleri tanımlanmıştır. $\mathrm{Bu}$ çalışma kapsamında uygulamada yaygın olarak tercih edilen ve yönetmelikte tanımlanan topuk genişliği, örtü kalınlığ1 ve loca genişliği gibi önemli tasarım parametreleri sayısal analiz yöntemleriyle değerlendirilmiştir.

Kayadan oyma depoların genellikle içerisinde açıldığg tüf ve ignimbiritler çok düşük birim hacim ağırlıklı, yüksek gözenekli ve çok düşük dayanımlı kaya sınıfında yer almaktadır. Söz konusu kayaçlar termal yalıtım ve kolay kazılabilirlik gibi özelliklerinden dolayı kaya oyma depolar açısından birçok avantaja sahip olmasına rağmen, kaya kütle özellikleri açısından zayıf-orta kaya niteliğindedir.

7 metreden daha geniş loca genişliklerinde maksimum düşey gerilme ve toplam deformasyon 
değerlerinde keskin bir artış göze çarpmaktadır. Hatta loca genişliğinin 10 metreye çıtığ 1 durumlarda sistem bir bütün (tek bir açıklık) gibi çalışarak kaya oyma deponun kenarlarında yer alan localarda çekme gerilmeleri oluşmaya başlamaktadır.

Kayadan oyma depoların üzerindeki yer alacak örtü kalınlığının 4.0 metreden az olması durumunda loca tavanlarında çekme gerilmeleri oluşmakta ve kaya oyma yapının duraylılığını olumsuz yönde etkilemektedir. Bundan dolay1, bölgede açılacak olan kayadan oyma depolarda örtü kalınlığ 4 metreden az olmamalıdır. $\mathrm{Bu}$ durum, 2017 yılında çıkarılan yönetmelikle büyük ölçüde uyum göstermektedir.

2 metreden daha az topuk genişliğine sahip localar şeklinde tasarlanan kaya oyma depolar, tek bir açıklık gibi davranmakta ve bundan dolayı orta bölümde yer alan localarda deformasyon miktarları kenarlara göre daha fazla olmaktadır. Kenarlarda yer alan loca tavanlarında meydana gelen toplam deformasyon $3 \mathrm{~mm}$ civarında gerçekleşirken, orta bölümdeki localarda bu değer 8.3 mm'ye kadar çıkmaktadır. Buna karşın, 2 metreden daha kalın topuk genişliklerinde her bir locanın tavanında oluşan deformasyon değerleri sabit kalıp, her bir loca ayrı bir açıklık gibi davranmaktadır. Bu durumda tüm localarda 2 ile $3 \mathrm{~mm}$ arasında değişen toplam deformasyonlar gözlenmiştir.

$\mathrm{Bu}$ çalışmada göz önünde bulundurulan kaya oyma depo projesi için topuk genişliğinin ilgili yönetmeliğe göre 2.60 ile 3.25 metre arasında olması gerekmektedir. Projede bu koşul sağlanmış ve herhangi bir duraysızlık problemi yaşanmadan proje tamamlanmıştır. Yine bu proje için, madencilikte kullanılan topuk tasarım tekniği göz önünde bulundurulduğunda topuğa gelecek gerilme ve topuğun dayanımı sırasıyla
$0.54 \mathrm{MPa}$ ve $2.29 \mathrm{MPa}$ olarak hesaplanmış olup, güvenlik katsayısı olarak 4.24 gibi güvenli koşulları fazlasıyla karşılayan bir değer elde edilmiştir. Topuk genişliklerinin gereğinden fazla olmasının sistemin duraylılığına ilave bir katkısı bulunmadığı gibi kaya oyma depolarda depolama kapasitenin azalmasina ve dolaysıyla ekonomik kayıplara neden olabilmektedir.

Bölgede kaya oyma depoların yapım koşulları incelendiğinde, kayanın kütle ve malzeme özellikleriyle birlikte loca genişlikleri çok fazla değişkenlik göstermezken, topoğrafik ve morfolojik koşullardan dolayı örtü kalınlığı bölgesel anlamda farklılık sunabilmektedir. Bundan dolayı topuk genişliğinin örtü kalınlığına karşı hassasiyetinin daha önemli olduğu düşünülmektedir. $\mathrm{Bu}$ bağlamda, optimum güvenlik katsayısını (2) sağlayacak topuk genişliği tasarımı için topuk genişlikleri 2 metreden az olmayacak şekilde, Topuk Genişliği=(Örtü Kalınlığı-1.9) 7.5 ilişkisi kullanılabilir. Uygun olmayan topuk ve loca genişliklerinde deformasyonlar deponun ortasinda yer alan localarda artmakta ve deponun tamamı tek bir açıklık gibi davranmaktadır. Kaya oyma depolar localar şeklinde planlandığından söz konusu yapıların tasarımında en önemli nokta locaların ayrı birer açıklık gibi davranmasının sağlanmasıdır. Bu koşul ancak uygun loca ve topuk genişliklerinin planlanmasıyla sağlanabilir. Tüm bu koşullar göz önünde bulundurulduğunda, 2017 yılında çıkarılan yönetmelikte topuk genişliğinin belirlenmesinde önerilen tasarım ölçütlerinin oldukça tutucu sonuçlar verdiği görülmektedir. Bundan dolayı her bir kaya oyma depo projesi için mevcut mühendislik jeolojisi koşulları göz önünde bulundurularak topuk tasarımının yapılması önerilmektedir. 


\section{KAYNAKLAR}

Aydan, Ö., Ulusay, R., 2003. Geotechnical and geoenvironmental characteristics of man-made underground structures in Cappadocia, Turkey. Engineering Geology, 6, 245-272.

Aydan, Ö., Ulusay, R., 2013. Geomechanical evaluation of Derinkuyu Antique Underground City and its implications in geoengineering. Rock Mechanics and Rock Engineering, 46, 731754.

Aydar, E., Schmitt, A.K., Çubukçu, H.E., Akin L., Ersoy, O., Şen, E., Duncan, R.A., Atici G., 2012. Correlation of ignimbrites in the central Anatolian volcanic province using zircon and plagioclase ages and zircon compositions. Journal of Volcanology and Geothermal Research, 213-214, 83-97.

Berndt-Ersöz, S., 2006. Phyrigian rock-cut shrines: Structure, Functional Cult Practice. LeidenXX, XXI, 206.

Bieniawski, Z.T., 1992. Method revisited: coal pillar strength formula based on field investigations. In: Proceedings of the workshop on coal pillar mechanics and design. U.S. Department of the Interior, Bureau of Mines, IC 9315, Pittsburgh, PA, 158-165.

Çorakbaş, F., 2012. The comparison of rock-cut architecture sites in Turkey and Italy with special emphasis on Cappadocia. World Applied Sciences Journal, 17(11),1445-1453.

Deere, D.U., Miller, R.P., 1966. Engineering classification and index properties of intact rock. Technical Report No: AFNL-TR-65-116, Kirtland Air Force Base Weapons Laboratory, New Mexico.

Dinçer, İ., Bostanc1, M., 2019. Capillary water absorption characteristics of some Cappadocian ignimbrites and the role of capillarity on their deterioration. Environmental Earth Sciences, 78, 7.

Dinçer, İ., Orhan, A., Frattini, P., Crosta, G.B., 2016. Rockfall at the heritage site of the Tatlarin Underground City (Cappadocia, Turkey). Natural Hazards, 82 (2), 1075-1098.
Harunoğulları, M., Kayar, S., 2015. Ortahisar'da (Ürgüp) doğal soğutmalı yeraltı depolarının coğrafi analizi. Coğrafyacılar Derneği Uluslararas1 Kongresi Bildiriler Kitab1, 21-23 Mayıs 2015, 74-84, Gazi Üniversitesi, Ankara.

Hoek, E., Carranza-Torres, C.T., Corkum, B., 2002. Hoek-Brown failure criterion-2002 edition. In: Proceedings of the Fifth North American Rock Mechanics Symposium, vol 1, Toronto, 267-273.

ISRM (International Society for Rock Mechanics), 2007. The complete ISRM suggested methods for rock characterization. In: Ulusay R, Hudson JA (eds), Testing and Monitoring: 1974-2006.

Kaşmer, Ö., Ulusay, R., 2013. Effects of geoengineering characteristics of the soft tuffs and environmental conditions on the rock-hewn historical structures at Zelve Open Air Museum (Cappadocia, Turkey). Environmental and Engineering Geosciences, 19(2), 149-171.

Logie, C.V., Matheson, G.M., 1982. A critical review of the current state of the art design of mine pillars. 1st International Conference Stability in Underground Mining. Vancouver (Ed. C.O. Brawner) 359-382.

Mark, C., 2006. The evolution of intelligent coal pillar design: 1981- 2006. Proceedings of 25th International Conference on Ground Control in Mining, Morgantown, West Virginia, 325-334.

Merve, J. N., 2003. New pillar strength formula for South African coal. Journal of the Southern African Institute of Mining and Metallurgy, 103(5), 281-292.

NBG, 1985. Norwegian Rock Mechanics Group: Handbook in Engineering Geology_rock (in Norwegian). Tapir, Trondheim.

Obert, L., Duvall, W.I., 1967. Rock Mechanics and the Design of Structures in Rock, John Wiley \& Sons Inc., New York, 542-545.

Özata, Ş., 2015. Kapadokya bölgesi kaya oyma yapı sorunları ve çözüm önerileri. Yıldız Teknik Üniversitesi Fen Bilimleri Enstitüsü, Yüksek Lisans Tezi, İstanbul, $160 \mathrm{~s}$. 
Ren, Q., Wang, F., Chen, B., Zhao, M., Peng, Z., Yang, M., 2020. Study on stability prediction of pillars based on Bieniawski Pillar Strength Formula: a case of a phosphate mine. Geotechnical and Geological Engineering, 38, 4033-4044. https:// doi.org/10.1007/s10706-020-01275-9.

Rocscience, 2019a. RS2, 2D finite element program for soil and rock applications. Rocscience Inc, Toronto, Canada.

Rocscience, 2019b. RocData, Rock, soil and discontinuity strength analysis. Rocscience Inc, Toronto, Canada.

Salamon, M.D.G., Munro, A.H., 1967. A study of the strength of coal pillars. Journal of the Southern African Institute of Mining and Metallurgy, 68, 55-67.

Sülükçü, S., 2019. Kapadokya Bölgesi'ndeki kayadan oyma yeraltı depolarının duraylılığının değerlendirilmesi. Doktora Tezi, Jeoloji Mühendisliği Bölümü, Hacettepe Üniversitesi, Ankara.

T.C. Resmi Gazete, 2017. Kayadan Oyma Yapıların Tasarım, Hesap ve Yapım Esaslarına Dair Yönetmelik, 18 Ekim 2017. Say1: 30214. Başbakanlık Basımevi, Ankara.

Temel, A., 1992. Petrological and geochemical properties of the Cappadocian explosive volcanism. PhD Thesis, Department of Geological Engineering, Hacettepe University, Ankara.

Topal, T., 1995. Formation and deterioration of fairy chimneys of the Kavak tuff in Ürgüp-Göreme area (Nevsehir-Turkey). PhD Thesis, Middle East Technical University, Ankara, Turkey.

Topal, T., Doyuran, V., 1995. Effect of discontinuities on the development of fairy chimneys in the Cappadocia region (Central Anatolia-Turkey). Turkish Journal of Earth Sciences, 4(1), 49-54.
Topal, T., Doyuran, V., 1997. Analysis of deterioration of the Cappadocian tuff. Environmental Geology, 34(1), 5-20.

Toprak, V., Keller, J., Schumacher, R., 1994. Volcanotectonic features of the Cappadocian Volcanic Province. In: International Volcanological Congress-IAVCEI, Ankara, Excursion Guide.

Tuncay, E., 2009. Rock rupture phenomenon and pillar failure in tuffs in the Cappadocia region (Turkey). International Journal of Rock Mechanics and Mining Sciences, 46, 1253-1266.

Ulusay, R., Aydan, Ö., 2018. The 2016 Hans Cloos Lecture: geo-engineering aspects on the structural stability and protection of historical man-made rock structures: an overview of Cappadocia Region (Turkey) in the UNESCO's World Heritage List. Bulletin of Engineering Geology and the Environment, 77, 457.

Ulusay, R., Aydan, Ö., Geniş, M., Tano, H., 2013. Stability assessment of Avanos Congress Centre (Cappadocia, Turkey) in soft tuffs through an integrated scheme of rock engineering methods. Rock Mechanics and Rock Engineering, 46, 1303-1321.

Ulusay, R., Gökçeoğlu, C., Topal, T., Sönmez, H., Tuncay, E., Ergüler, Z.A., Kasmer, Ö., 2006. Assessment of environmental and engineering geological problems for the possible re-use of an abandoned rock-hewn settlement in Ürgüp (Cappadocia), Turkey. Environmental Geology, 50(4), 473-449.

Yavuz, H., 2001. Yielding pillar concept and its design. 17th International Mining Congress and Exhibition of Turkey- MCET 2001, ISBN 975395-417-4.

Zhu, X., Liu, J., Yang, L. Hu, R., 2014. Energy performance of a new Yaodong Dwelling, in the Loess Plateau of China. Energy and Buildings, 70, 159-166. 